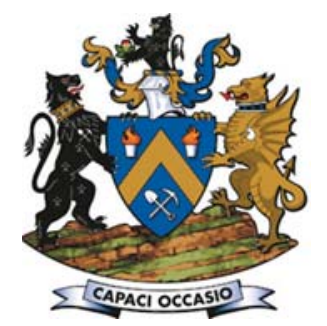

\title{
An empirical long-term commodity price range for Mineral Reserve declarations to minimize impairments in gold and platinum mines
}

\author{
by V. Maseko ${ }^{1}$ and C. Musingwini ${ }^{2}$
}

\begin{abstract}
Synopsis
When considered collectively, Mineral Resources and Mineral Reserves are arguably a key asset for any mining company. Mineral Reserves are the economically mineable portions of Mineral Resources. They therefore provide a good indication of the economic prospects in the short to medium term and associated non-financial impairments for mining companies, hence a focus on Mineral Reserves. An assessment of modifying factors for converting Mineral Resources to Mineral Reserves revealed that Mineral Reserves were most sensitive to long-term commodity prices, hence the focus on long-term commodity prices. The justification for selecting gold and platinum mines is that they collectively make a significant contribution to South Africa's earnings from mining.

The introduction of the South African Code for the Reporting of Exploration Results, Mineral Resources and Mineral Reserves (SAMREC Code) in 2000 informed the basis for analysing long-term commodity price assumptions for major South African gold and platinum mining companies between 2000 and 2016. The analysis revealed that the least number of non-financial impairments occurred when long-term commodity prices were within $\pm 5 \%$ of spot prices. This finding suggests that this range is the ideal range for long-term commodity price assumptions to improve confidence in Mineral Reserve declarations and minimize impairments.

Keywords

modifying factors, long-term commodity prices, spot prices, impairment, reporting codes.
\end{abstract}

(the JORC Code), a Mineral Reserve is synonymous with an Ore Reserve. The conversion of Mineral Resources to Mineral Reserves involves applying modifying factors, which are non-resource considerations. The modifying factors used in the Mineral Reserve estimation process include mining, metallurgical, processing, infrastructure, economic, marketing, legal, environmental, social, and governmental factors. Each of these modifying factors consists of several components which require due consideration in the estimation of Mineral Reserves. Table I shows some of the components typically considered for each of the modifying factors.

It can be argued that, considered collectively, Mineral Resources and Mineral Reserves are the single most significant asset or among the most significant assets for any mining company (Njowa and Musingwini, 2018). International reporting codes provide the minimum standards and guidelines for the estimation, declaration, and public reporting of Exploration Results, Mineral Resources, and Mineral Reserves. The reporting of Exploration Results, Mineral Resources, and Mineral Reserves serves the needs of governments, international organizations, investors and potential investors and their advisors (SAMREC, 2016). International organizations are interested in the in situ estimates of mineral inventories to inform world perspectives on strategic and critical minerals, while governments rely on these estimates to design policies for safeguarding their mineral endowments and ensuring that their citizens can benefit from the exploitation of those minerals (Musingwini, 2018). Investors are

1 Ernst \& Young Advisory Services Limited, South Africa.

2 School of Mining Engineering, University of the Witwatersrand, South Africa.

(C) The Southern African Institute of Mining and Metallurgy, 2019. ISSN 2225-6253. Paper received Aug. 2018; revised paper received Jan. 2019. 


\section{An empirical long-term commodity price range for Mineral Reserve declarations}

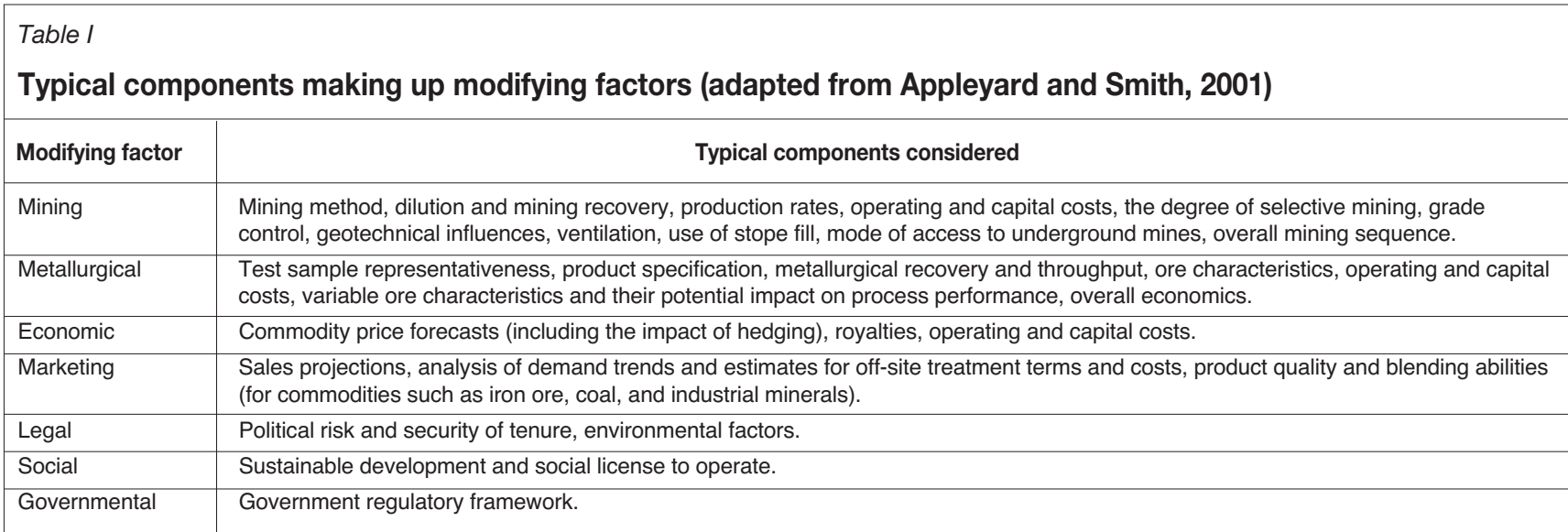

interested in the economically extractable portion of the mineral deposit as this is a good indicator of the economic prospects for mining companies in the short to medium term. Securities exchanges worldwide have an overarching principle of protecting investors and so require transparent and consistent reporting of Mineral Resources and Mineral Reserves for easier decision-making by investors. The national reporting code in South Africa is the SAMREC Code. The SAMREC Committee (now SAMCODES Standards Committee or SSC) first published the SAMREC Code in March 2000 and later that year the Johannesburg Stock Exchange (JSE) adopted the Code, requiring compliance with the Code as part of the Listing Requirements for mining companies.

The reporting codes are principles-based and therefore not prescriptive. This gives the Competent Person (CP) some discretion in estimating and reporting Mineral Resources and Mineral Reserves, if their approaches and methodologies are reasonable and defendable. The discretion includes assumptions on modifying factors. The 2016 Edition of the SAMREC Code attempted to address the shortcomings associated with the discretion exercised by CPs by introducing the 'if not, why not' reporting principle. This principle requires that CPs must report on every aspect as specified in Table I of the SAMREC Code, otherwise they need to provide reasonable justification for not reporting on certain elements (Lomberg and Rupprecht, 2017). This principle makes it more difficult for a $\mathrm{CP}$ to be selective when reporting, thus enabling the $\mathrm{CP}$ to include all the information that stakeholders, investors, potential investors, and advisors would reasonably expect to find in a public report (Lomberg and Rupprecht, 2017). One of the modifying factors for which a CP needs to exercise reasonable discretion is longterm commodity prices. Long-term commodity prices are one of the most important modifying factors used in Mineral Reserve estimation. Mineral Reserves are the economically mineable portions of Mineral Resources; hence, they provide a better indication of the economic prospects for mining companies in the short to medium term. In order to minimize variations in long-term commodity price assumptions, this research study undertook to estimate an ideal range of longterm commodity prices relative to spot prices. By minimizing variations, it should be possible to improve confidence in the reporting of Mineral Reserves.

\section{Importance of long-term commodity prices in estimating Mineral Reserves}

Commodity prices are very important in the Mineral Reserve estimation process. For example, as Appleyard (2001, p. 8) argued, 'the most sensitive inputs to a mine valuation are those which relate to revenue. While metallurgical recovery directly relates to revenue, the factors which are usually subject to most variation are the price for the commodity'. Conducting a valuation is a critical step in establishing the economic viability of Mineral Reserves. Therefore, the statement by Appleyard (2001) indicates that although all other modifying factors are important in the estimation of Mineral Reserves, commodity price assumptions are the most important modifying factor. However, commodity prices fluctuate over time as dictated by market forces and international reporting codes do not require the revision of Mineral Reserve estimates due to short-term commodity price movements. Another revenue driver, which is critical to the mine valuation process, is grade, as grade (together with production volumes and metallurgical recovery) is a key driver of saleable product volumes to which commodity prices are applied to estimate revenue. The reporting codes provide guidance on the use of long-term price assumptions for Mineral Reserves estimation. The arguments put forward by authors such as Appleyard and Smith (2001), and Baker and Giacomo (2001) are in agreement with these guidelines of the reporting codes.

Appleyard and Smith (2001, p. 327) argued that the 'failure to recognise that a price decrease means that a previous Ore Reserve is now a body of uneconomic mineralisation, can cause a company to continue operating until it is in a position where it can fail'. This argument indicates that in a volatile commodity market, commodity price decreases significantly affect the quantum of Mineral Reserves and can impair the economic viability of a mining operation if they persist in the long term. Baker and Giacomo (2001, p. 669) also argued that commodity prices are critical in that 'fundamental to the determination of reserves (and to a lesser extent resources) is the underlying metal price assumptions used in the estimation. Contained metal can be highly sensitive to metal price assumptions employed, especially where the margin between cost and revenue is small. At best, a company could consider providing sensitivities of tonnes and grade to commodity price 


\section{An empirical long-term commodity price range for Mineral Reserve declarations}

assumptions. At the very least we are of the view that companies should disclose the price at which the

determinations are made (in appropriate currencies)'. This argument indicates that Mineral Reserve estimates are very sensitive to commodity prices. It was therefore, necessary to explore the impact that commodity price assumptions have on Mineral Reserves, but also simultaneously evaluating the impacts of other modifying factors on Mineral Reserves to obtain a balanced view.

\section{Methodology}

In order to address the objective set out for this research study, firstly it was necessary to review the annual reports and other publications (available in the public domain) of major South African gold and platinum mining companies to establish their long-term commodity price assumptions. The review focused on the period from 2000 to 2016, which is associated with improved Mineral Resource and Mineral Reserve reporting following the introduction of the SAMREC Code in 2000. The selection of gold and platinum mining was premised on the fact that these two commodities contribute a significant portion of South Africa's earnings from mining, together making up approximately $44 \%$ and $37 \%$ of mining income in 2012 and 2015, respectively (Table II). The other major South African commodities, which are coal and iron ore, were not included in this research study since they consist of many different product types and trade differently, usually under contractual agreements. The prices of these other major commodities are thus set in contractual agreements, unlike the more fungible gold and platinum commodities that trade openly in commodity exchange markets where market forces drive commodity spot prices.

The second step entailed comparing the long-term commodity price assumptions of the major South African gold and platinum mining companies to actual prices from 2000 to 2016. This comparison provided a basis for establishing the reasonability of the long-term commodity prices used by South Africa's gold and platinum mining companies in their Mineral Reserve estimations and declarations.
The third step involved evaluating correlations between the long-term commodity price assumptions and the other modifying factors, and the Mineral Reserve declarations of the major South African gold and platinum mining companies from 2000 to 2016 to determine if long-term commodity prices had the most significant impact on the Mineral Reserve estimates. Lastly, it was necessary to make an estimation of the ideal range for the long-term commodity price assumptions for the Mineral Reserve estimates for South African gold and platinum mining companies based on the price range associated with the least number of impairments. The following paragraphs explain the concept of impairment and describe the link between commodity prices and impairments.

Commodity price is a primary driver of value for mining companies (MacDiarmid, Tholana, and Musingwini, 2018). Therefore, commodity price fluctuations will affect the company value reported by mining companies in their financial statements. Financial statements typically capture the assets of mining companies as either tangible assets, such as property, plant, and equipment, or intangible assets associated with mining rights. The long-term commodity prices assumed by mining companies have a direct impact on the value of the assets associated with mining rights.

The International Accounting Standard 36 (IAS 36) is an accounting standard that provides guidance to companies for the impairment of assets. IAS 36 states that company financial statements should not carry (or record) the assets at a value which is greater than would be recoverable through use or sale. If the carrying value exceeds the recoverable value, then a company should recognize an impairment. IAS 36 does not cover financial assets, inventories, deferred tax, and other assets as other accounting standards provide guidance for their impairment (IFRS Foundation, n.d.).

The impairments recorded by mining companies for their non-financial assets are a reliable proxy of the effects of their long-term commodity price assumptions. Where mining companies record the value of their property, plant, and equipment or the value of their mining rights on their financial statements using long-term commodity prices that

Table II

Income contribution by the various mining sectors in South Africa for 2012 and 2015 (source: Statistics South Africa, 2017)

\begin{tabular}{|c|c|c|c|c|}
\hline \multirow[t]{2}{*}{ Type of mining } & \multicolumn{2}{|c|}{2012} & \multicolumn{2}{|c|}{2015} \\
\hline & R million & $\%$ Contribution & $\mathrm{R}$ million & $\%$ Contribution \\
\hline $\begin{array}{l}\text { Coal and lignite } \\
\text { Gold and uranium ore } \\
\text { Iron ore } \\
\text { Chrome ore } \\
\text { Manganese ore } \\
\text { Platinum group metal ore } \\
\text { Dimension stone (granite, marble, slate and sandstone) } \\
\text { Limestone and limeworks } \\
\text { Other stone quarrying, including stone crushing and clay and sandpits } \\
\text { Diamonds (including alluvial diamonds) } \\
\text { Other chemical and fertilizer minerals } \\
\text { Extraction and evaporation of salt } \\
\text { Other mining activities and service activities incidental to mining } \\
\text { Other minerals and materials n.e.c. } \\
\text { Total }\end{array}$ & $\begin{array}{c}96097 \\
66957 \\
68061 \\
11412 \\
10254 \\
106555 \\
630 \\
2398 \\
10289 \\
8694 \\
3330 \\
280 \\
7822 \\
582 \\
393361\end{array}$ & $\begin{array}{c}24.4 \\
17.0 \\
17.3 \\
2.9 \\
2.6 \\
27.1 \\
0.2 \\
0.6 \\
2.6 \\
2.2 \\
0.8 \\
0.1 \\
2.0 \\
0.1 \\
100.0\end{array}$ & $\begin{array}{c}117958 \\
63674 \\
60699 \\
16383 \\
17093 \\
91099 \\
1146 \\
2717 \\
16584 \\
15055 \\
5976 \\
215 \\
10295 \\
639 \\
419533\end{array}$ & $\begin{array}{c}28.1 \\
15.2 \\
14.5 \\
3.9 \\
4.1 \\
21.7 \\
0.3 \\
0.6 \\
4.0 \\
3.6 \\
1.4 \\
0.1 \\
2.5 \\
0.2 \\
100.0\end{array}$ \\
\hline
\end{tabular}




\section{An empirical long-term commodity price range for Mineral Reserve declarations}

are considerably higher than prevailing spot commodity prices, an impairment may be triggered since the recoverable value of the non-financial assets may be exceeded by the carrying value, in line with the provisions of IAS 36. Impairments can also be recorded when long-term commodity prices are considerably lower than prevailing prices, as the perceived recoverable value (as represented by long-term commodity price assumptions) may be lower than current carrying values. Therefore, impairments can occur under conditions of either excessive optimism or conservatism in long-term commodity price assumptions.

\section{South African gold and platinum mining companies' long-term price assumptions}

It was necessary to assess the long-term commodity price assumptions relative to spot prices, as this would assist in evaluating how these assumptions influenced Mineral Reserve declarations. An analysis by Barclays Bank plc (2015) concluded that $65 \%$ of the South African platinum mining industry was cash flow negative at 2015 spot prices, compared to only $22 \%$ of the South African gold mining industry. The better performance by the gold mining sector is probably attributable to a better performing gold price compared to the platinum price pre- and post-2015. However, the quality of investment and operational decisions between the two sectors (based on their long-term commodity price assumptions) could also have partly contributed to differences in their financial performance. Figure 1 indicates that South African gold mining companies adopted more conservative long-term price assumptions for their Mineral Reserve estimations relative to the 2015 gold average spot price, with the exception of Harmony Gold, which assumed a long-term price which was higher than the average spot price (Barclays Bank plc, 2015). As argued earlier, these conservative assumptions would have informed the operational and investment decisions of the South African gold mining companies, which may have contributed to their better cash flow positions compared to platinum mining companies.

Figures 2 and 3 illustrate the platinum group metals (PGMs) basket price assumptions relative to average spot prices between 2006 and 2016 for Lonmin plc (Lonmin) and Impala Platinum Holdings Limited (Impala), respectively. A

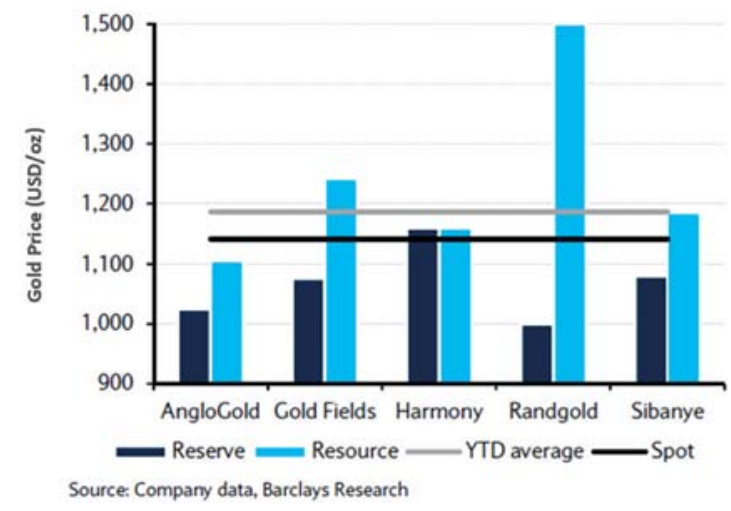

Figure 1-Long-term commodity prices used in Mineral Resource and Mineral Reserve estimations for South African gold mining companies in 2015 (source: Barclays Bank plc, 2015) commodity basket price for a multi-metal deposit is obtained by considering the recoverable proportions of the individual metals found in the deposit and their respective prices, taking into account market considerations.

Figure 2 shows that for the period 2008 to 2014, Lonmin consistently assumed long-term PGM basket prices that were considerably higher than the spot prices. This optimistic long-term price outlook would probably have contributed to the poor investment choices made by Lonmin in bringing the K4 shaft into production in 2011. Persistent weak PGM prices rendered the project financially unviable and Lonmin had to place the K4 shaft on care and maintenance in November 2012 (Barclays Bank plc, 2014). Figure 3 indicates that had Impala adopted a long-term PGM basket price closer to spot prices in 2016, its Mineral Reserves would have halved, although the long-term PGM basket price assumed by Impala was 30\% above spot prices (Impala, 2016). This shows the significant effect of long-term commodity price assumptions on Impala's Mineral Reserve estimates.

Figure 4 illustrates the 2015 South African gold production cost curve, which explains why South African gold mines were mostly cash flow positive in 2015 (Barclays Bank plc, 2015). It was mostly operations owned by Harmony Gold (indicated as 'HAR' in Figure 4) which were in the upper quartile of the cost curve. This is partly the reason why Harmony Gold mines were loss-making in 2015, although this could also have been due to fact that the mines have some of the lowest grades in the South African gold mining sector. The global PGM cost curve in Figure 5

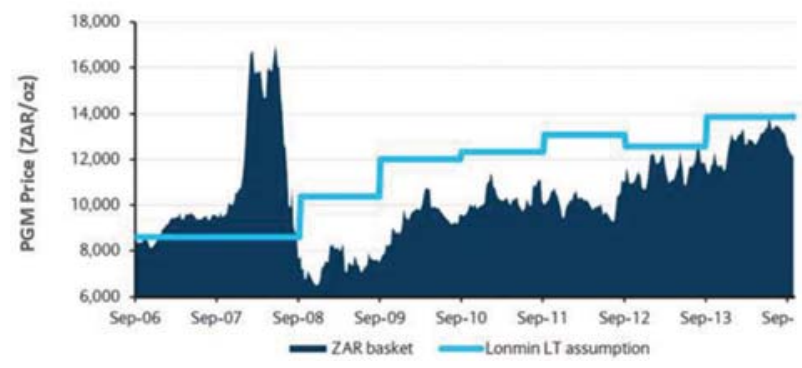

Figure 2-PGM basket prices compared to long-term price assumptions for Lonmin between 2006 and 2014 (source: Barclays Bank plc, 2014)

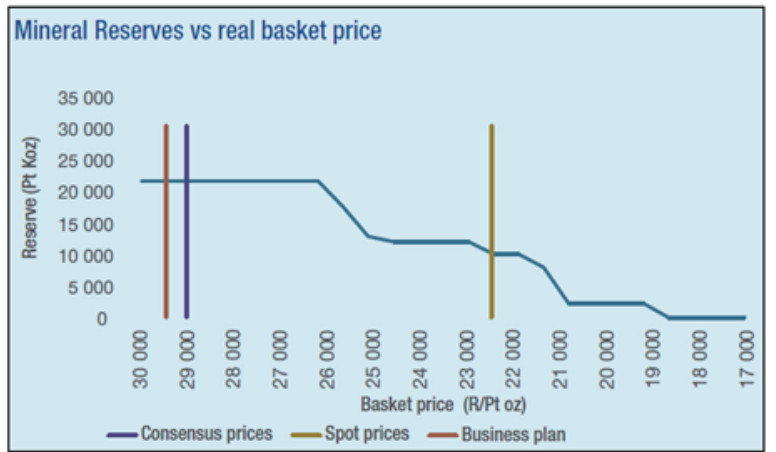

Figure 3-Impala's Mineral Reserve PGM basket prices for 2016 (in South African rands per ounce) compared to long-term basket and consensus prices (source: Impala Platinum Holdings Limited, 2016) 


\section{An empirical long-term commodity price range for Mineral Reserve declarations}

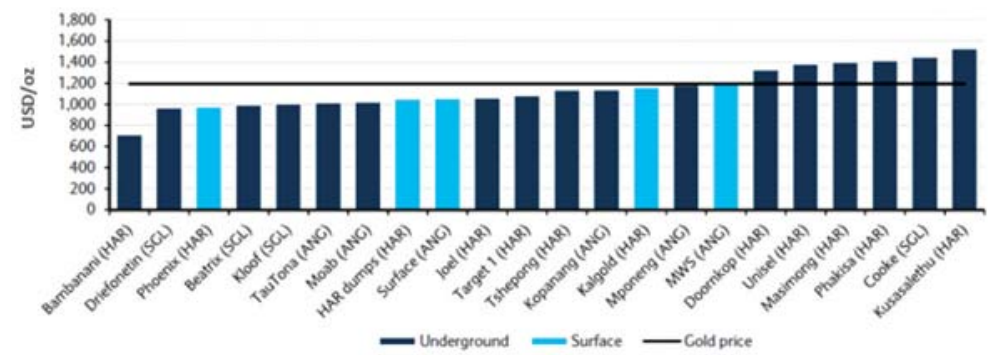

Figure 4-South African gold production cost curve in 2015 (source: Barclays Bank plc, 2015)

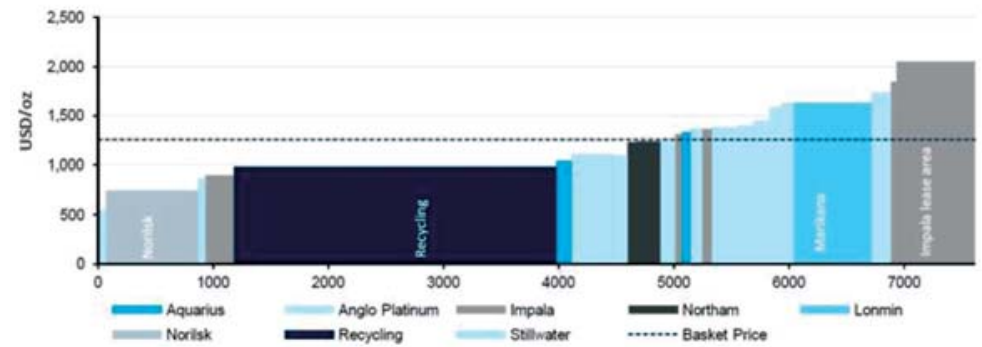

Figure 5-Global PGM cost curve, including capex, in 2014 (source: Barclays Bank plc, 2014)

Table III

Gold and PGM prices for the period 2000 to 2016 (sources: SNL Metals \& Mining, n.d.; Kitco, n.d.; Metalary, n.d,; Quandl, n.d)

\begin{tabular}{|c|c|c|c|c|c|c|c|c|c|c|c|c|}
\hline Year & $\begin{array}{c}\text { Gold } \\
\text { (US\$/oz) }\end{array}$ & $\begin{array}{l}\text { Platinum } \\
\text { (US\$/oz) }\end{array}$ & $\begin{array}{c}\text { Palladium } \\
\text { (US\$/oz) }\end{array}$ & $\begin{array}{l}\text { Rhodium } \\
\text { (US\$/oz) }\end{array}$ & $\begin{array}{l}\text { Iridium } \\
\text { (US\$ /oz) }\end{array}$ & $\begin{array}{c}\text { Ruthenium } \\
\text { (US\$/oz) }\end{array}$ & $\begin{array}{c}\text { Gold } \\
\text { (ZAR/oz) }\end{array}$ & $\begin{array}{l}\text { Platinum } \\
\text { (ZAR/oz) }\end{array}$ & $\begin{array}{c}\text { Palladium } \\
\text { (ZAR/oz) }\end{array}$ & $\begin{array}{l}\text { Rhodium } \\
\text { (ZAR/oz) }\end{array}$ & $\begin{array}{l}\text { Iridium } \\
\text { (ZAR/oz) }\end{array}$ & $\begin{array}{c}\text { Ruthenium } \\
\text { (ZAR/oz) }\end{array}$ \\
\hline 2016 & 1249 & 987 & 613 & 663 & 575 & 40 & 18367 & 14525 & 9020 & 9750 & 8460 & 588 \\
\hline 2015 & 1160 & 1052 & 692 & 919 & 544 & 42 & 14798 & 13421 & 8826 & 11731 & 6936 & 536 \\
\hline 2014 & 1266 & 1384 & 803 & 1128 & 556 & 58 & 13731 & 15009 & 8710 & 12237 & 6027 & 629 \\
\hline 2013 & 1411 & 1485 & 725 & 1075 & 826 & 57 & 13618 & 14339 & 7002 & 10377 & 7975 & 550 \\
\hline 2012 & 1669 & 1549 & 644 & 1270 & 1070 & 90 & 13699 & 12720 & 5290 & 10425 & 8786 & 739 \\
\hline 2011 & 1572 & 1719 & 733 & 1990 & 1036 & 110 & 11417 & 12488 & 5328 & 14455 & 7527 & 799 \\
\hline 2010 & 1226 & 1611 & 526 & 2384 & 642 & 180 & 8977 & 11792 & 3854 & 17451 & 4702 & 1318 \\
\hline 2009 & 973 & 1205 & 264 & 1442 & 425 & 160 & 8249 & 10211 & 2235 & 12218 & 3605 & 1356 \\
\hline 2008 & 872 & 1571 & 352 & 6455 & 450 & 110 & 7203 & 12980 & 2909 & 53321 & 3718 & 909 \\
\hline 2007 & 697 & 1305 & 355 & 6076 & 447 & 415 & 4909 & 9192 & 2499 & 42805 & 3149 & 2924 \\
\hline 2006 & 604 & 1142 & 321 & 4442 & 350 & 610 & 4093 & 7733 & 2172 & 30086 & 2368 & 4131 \\
\hline 2005 & 445 & 897 & 202 & 2002 & 169 & 87 & 2832 & 5705 & 1282 & 12732 & 1078 & 553 \\
\hline 2004 & 410 & 846 & 230 & 904 & 186 & 68 & 2648 & 5464 & 1485 & 5839 & 1204 & 439 \\
\hline 2003 & 364 & 692 & 199 & 475 & 93 & 41 & 2753 & 5233 & 1508 & 3596 & 704 & 310 \\
\hline 2002 & 310 & 540 & 337 & 768 & 294 & 40 & 3272 & 5688 & 3548 & 8095 & 3095 & 422 \\
\hline 2001 & 271 & 529 & 604 & 1582 & 413 & 80 & 2334 & 4557 & 5199 & 13623 & 3556 & 689 \\
\hline 2000 & 279 & 545 & 743 & 1993 & 415 & 160 & 1937 & 3780 & 5155 & 13832 & 2880 & 1110 \\
\hline
\end{tabular}

indicates that South African platinum mines were mostly cash flow negative in 2014 (Barclays Bank plc, 2014). These observations suggest that there is a relationship between financial performance and long-term commodity price assumptions.

Commodity prices fluctuate due to supply and demand dynamics. In the case of gold and PGMs, the period from 2000 to 2008 was marked by a general upward trend in the prices of these precious metals. However, following the 2008 Global Financial Crisis, the precious metal prices that had peaked crashed rapidly in 2009 , followed by marginal recoveries in 2010 to 2012. Table III and Figure 6 indicate that precious metal prices continued to experience downward trends in US dollar terms. The US dollar-denominated gold and PGM prices have shown a general downward trend from 2012 to 2016, while the South African rand- (ZAR)denominated commodity prices have shown a general positive trend from 2000 to 2016 . The general depreciation of the rand against the US dollar in periods of weak US dollardenominated commodity prices is the major reason for this . South African gold and platinum mining companies have therefore made their long-term commodity price assumptions in an increasing rand-price environment between 2000 and 2016.

South Africa's major gold mining companies have generally reported on the long-term gold price assumptions 


\section{An empirical long-term commodity price range for Mineral Reserve declarations}

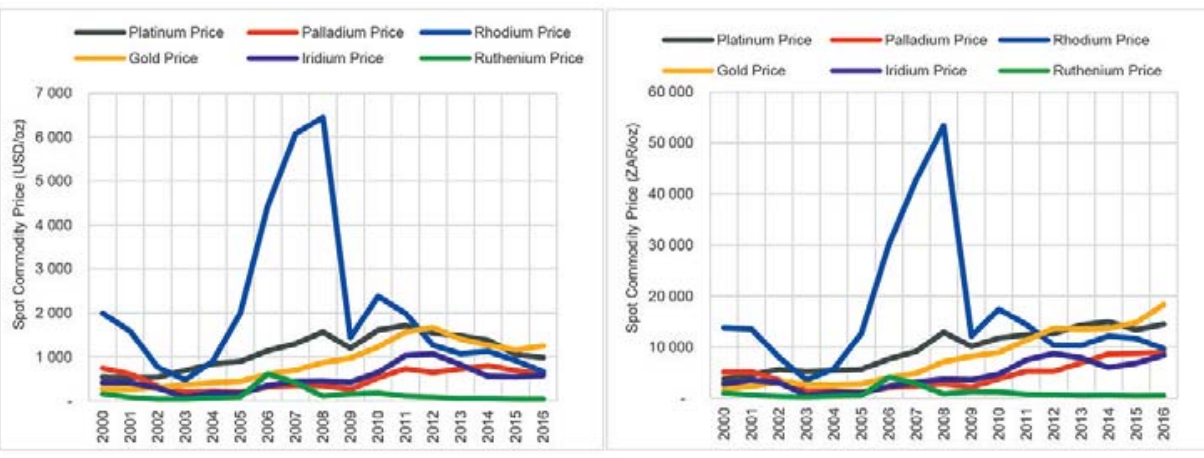

Figure 6-Gold and PGM prices for the period 2000-2016 (sources: SNL Metals \& Mining, n.d.; Kitco, n.d.; Metalary, n.d.; Quandl, n.d.)

used in their Mineral Reserve declarations. Table IV shows that by 2001, a year after the introduction of the SAMREC Code, the three major South African gold producers started reporting their long-term gold price assumptions. Table IV and Figure 7 also show that between 2000 and 2016, South African gold mining companies assumed long-term gold prices, in rand per kilogram terms, that were consistently either lower than or in line with prevailing spot prices. This suggests that South African gold mining companies had a lower probability of reporting unprofitable ounces as part of their Mineral Reserves in the period from 2000 to 2016. The abbreviation 'NR' means 'not reported' and 'N/A' means 'not applicable'. For example, in Table IV, Sibanye Gold did not exist as a gold mining company hence 'N/A' is used between 2000 and 2011.

The history of South African platinum mining companies as regards reporting long-term price assumptions in Mineral Reserve declaration between 2000 and 2016 has been less detailed than that of the gold mining companies. Implats and Northam began reporting on long-term platinum prices only in 2003, followed by Lonmin in 2005; while Anglo American Platinum (Amplats) did not report its long-term price assumptions in the period under review, as shown in Table $\mathrm{V}$. Figure 8 and Table V show that between 2003 and 2016, South African platinum mining companies generally reported long-term platinum prices that were higher than prevailing spot prices. Implats' long-term platinum prices have often been the most bullish throughout the period under review, while Northam's long-term prices have been relatively conservative. Figure 9 shows that for the other PGMs, South African platinum mining companies have generally reported long-term prices higher than spot prices for palladium between 2000 and 2016 and more optimistic long-term prices (relative to spot) for rhodium between 2009 and 2016. However, for gold and iridium, South African platinum mining companies have generally reported long-term prices that were lower than spot prices. The reporting trends of South African platinum mining companies suggest that between 2000 and 2016, they were more likely than gold mining companies to report uneconomic ounces as part of their Mineral Reserves. Persistent reporting of uneconomic ounces can trigger impairment.

\section{Correlations between modifying factors and reported Mineral Reserves}

As discussed earlier, Appleyard (2001) suggested that

\begin{tabular}{|c|c|c|c|c|c|}
\hline \multicolumn{6}{|c|}{ Table IV } \\
\hline \multicolumn{6}{|c|}{$\begin{array}{l}\text { Average spot gold prices and long-term gold } \\
\text { price assumptions from } 2000 \text { to } 2016 \text { (sources: } \\
\text { SNL Metals \& Mining, n.d.; AngloGold Ashanti, } \\
\text { 2000-2016; Harmony Gold, 2000-2016; Gold Fields, } \\
\text { 2000-2016,; Sibanye Gold, 2013-2016) }\end{array}$} \\
\hline \multirow[t]{2}{*}{ Year } & \multirow{2}{*}{$\begin{array}{l}\text { Spot gold price } \\
\text { (ZAR/kg) }\end{array}$} & \multicolumn{4}{|c|}{ Long-term gold price assumptions (ZAR/kg } \\
\hline & & $\begin{array}{c}\text { AngloGold } \\
\text { Ashanti }\end{array}$ & $\begin{array}{c}\text { Harmony } \\
\text { Gold }\end{array}$ & $\begin{array}{l}\text { Gold } \\
\text { Fields }\end{array}$ & $\begin{array}{c}\text { Sibanye } \\
\text { Gold }\end{array}$ \\
\hline 2016 & 590 & & 7 & 5 & 490000 \\
\hline 2015 & 47 & 4 & . & 500 & 430000 \\
\hline 2014 & 441465 & 398 & 425064 & 400 & 420000 \\
\hline 2013 & 437828 & 360 & 400148 & 400 & 410000 \\
\hline 2012 & 440417 & 290064 & 339833 & 380000 & 380000 \\
\hline 2011 & 367051 & 269841 & 279888 & 310000 & N/A \\
\hline 2010 & 288628 & 238028 & 250149 & 265000 & $\mathrm{~N} / \mathrm{A}$ \\
\hline 2009 & 265204 & 227627 & 224975 & 230000 & N/A \\
\hline 2008 & 2315 & 20 & 179 & & $\mathrm{~N} / \mathrm{A}$ \\
\hline 2007 & 1578 & 148 & 115 & 100 & N/A \\
\hline 2006 & 131587 & 11 & 104 & 920 & N/A \\
\hline 2005 & 91065 & 86807 & 91996 & 92000 & N/A \\
\hline 2004 & 85121 & 764 & 91996 & 90000 & N/A \\
\hline 2003 & 88522 & 78769 & 92948 & 95000 & N/A \\
\hline 2002 & 105194 & 94041 & & 95111 & N/A \\
\hline 2001 & 75056 & 71262 & 673 & 69992 & N/A \\
\hline 2000 & 62279 & NR & 60033 & NR & N/A \\
\hline
\end{tabular}

NR Not reported N/A Not applicable

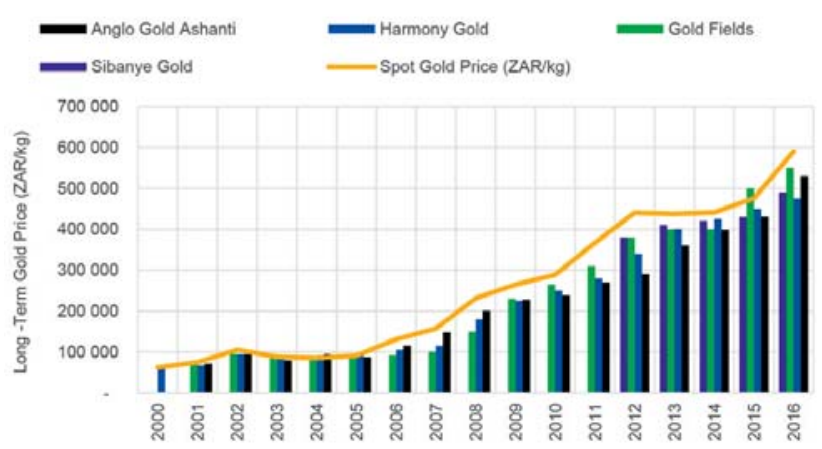

Figure 7-Long-term gold price assumptions relative to spot prices from 2000 to 2016 (sources: SNL Metals \& Mining, n.d.; AngloGold Ashanti, 2000-2016; Harmony Gold, 2000-2016; Gold Fields, 2000-2016; Sibanye Gold, 2013-2016) 


\section{An empirical long-term commodity price range for Mineral Reserve declarations}

\begin{tabular}{|c|c|c|c|c|c|c|}
\hline \multicolumn{7}{|c|}{ Table V } \\
\hline \multicolumn{7}{|c|}{$\begin{array}{l}\text { Historical average spot platinum prices and long-term platinum price assumptions from } 2000 \text { to } 2016 \text { (sources: } \\
\text { SNL Metals \& Mining, n.d.; Impala Platinum Holdings, 2000-2016; Northam Platinum, 2000-2016; Lonmin plc, } \\
\text { 2000-2016; Anglo American Platinum, 2000-2016; Sibanye, } \\
\text { 2013-2016) }\end{array}$} \\
\hline \multirow[t]{2}{*}{ Year } & \multirow{2}{*}{$\begin{array}{c}\text { Spot platinum price } \\
\text { (ZAR/oz) }\end{array}$} & \multicolumn{5}{|c|}{ Long-term platinum price assumptions (ZAR/oz) } \\
\hline & & Impala Platinum Holdings Limited & Northam Platinum & Lonmin Plc & Anglo American Platinum & Sibanye Platinum \\
\hline 2016 & 14525 & 18648 & 20291 & 20729 & NR & 15500 \\
\hline 2015 & 13421 & 17718 & 19357 & 18632 & NR & N/A \\
\hline 2014 & 15009 & 26760 & 13455 & 16785 & NR & N/A \\
\hline 2013 & 14339 & 18778 & 15925 & 16785 & NR & N/A \\
\hline 2012 & 12720 & 16080 & 11963 & 14875 & NR & $\mathrm{N} / \mathrm{A}$ \\
\hline 2011 & 12488 & 22560 & 12866 & 15200 & NR & N/A \\
\hline 2010 & 11792 & 27716 & 12360 & 14904 & NR & N/A \\
\hline 2009 & 10211 & 20879 & 9450 & 14400 & NR & N/A \\
\hline 2008 & 12980 & 24083 & 14391 & 12000 & NR & N/A \\
\hline 2007 & 9192 & 11085 & 6670 & 9208 & NR & N/A \\
\hline 2006 & 7733 & 7850 & 5850 & 7700 & NR & $\mathrm{N} / \mathrm{A}$ \\
\hline 2005 & 5705 & 6700 & 4950 & 4940 & NR & N/A \\
\hline 2004 & 5464 & 6100 & 4347 & NR & NR & N/A \\
\hline 2003 & 5233 & 6100 & 5004 & NR & NR & N/A \\
\hline 2002 & 5688 & NR & NR & NR & NR & N/A \\
\hline 2001 & 4557 & NR & NR & NR & NR & N/A \\
\hline 2000 & 3780 & NR & NR & NR & NR & N/A \\
\hline
\end{tabular}

NR: Not reported

N/A Not applicable

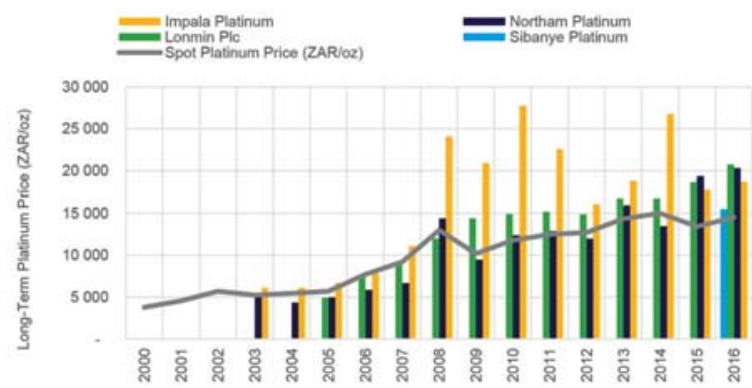

Figure 8-Long-term platinum price assumptions relative to spot prices, 2000-2016 (sources: SNL Metals \& Mining, n.d.; Impala Platinum Holdings, 20002016; Northam Platinum, 2000-2016; Lonmin plc, 2000-2016; Anglo American Platinum, 2000-2016; Sibanye, 2013-2016)

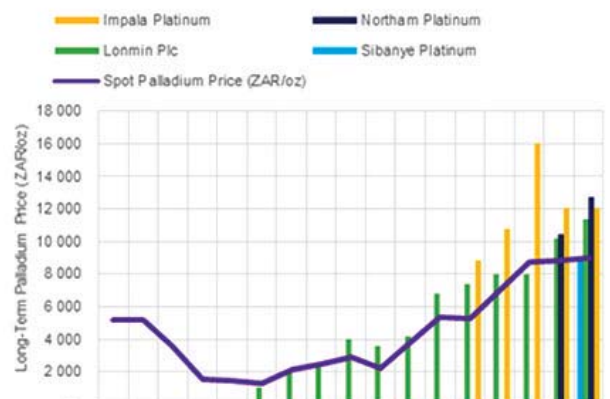

实

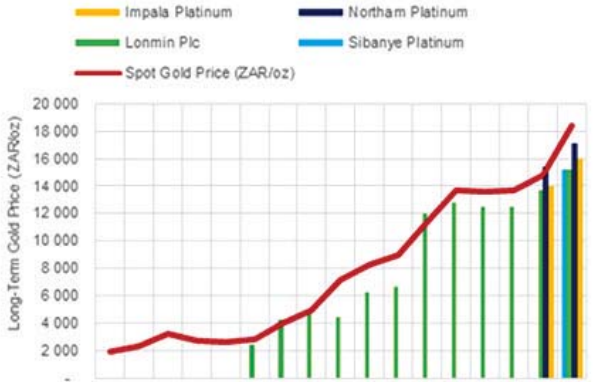

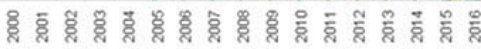

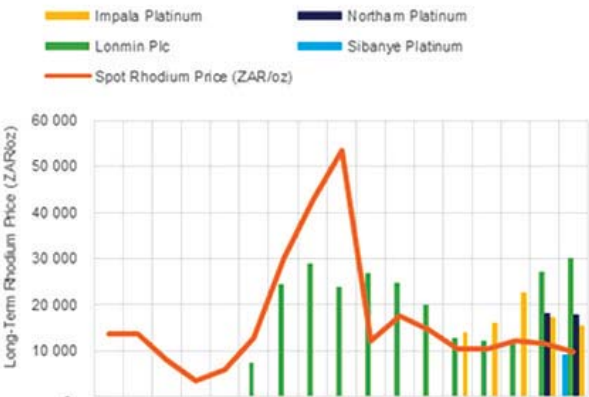

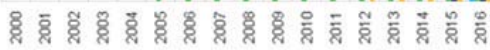

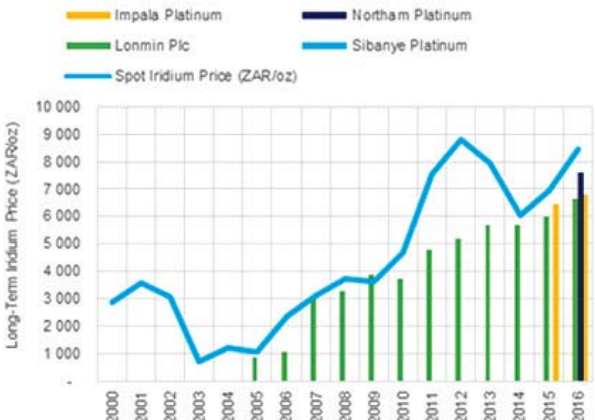

Figure 9-Long-term PGM price assumptions relative to spot prices 2000-2016 (sources: SNL Metals \& Mining, n.d.; Kitco, n.d.; Metalary, n.d.; Quandl, n.d.; Impala Platinum Holdings (2000-2016); Northam Platinum (2000-2016); Lonmin plc (2000-2016); Anglo American Platinum, 2000-2016; Sibanye, 2013-2016) 


\section{An empirical long-term commodity price range for Mineral Reserve declarations}

Mineral Reserves are most sensitive to commodity prices among the modifying factors. However, other modifying factors are also important for Mineral Reserve estimation. It was therefore necessary to establish the relationship between the Mineral Reserve estimates of South African gold and platinum mining companies and their reported modifying factors. The coefficient of determination $\left(R^{2}\right)$ was used to assess the relationship between Mineral Reserve estimates and modifying factors. $\mathrm{R}^{2}$ measures the correlation between two variables by determining how changes in the independent variable affect the dependent variable. $\mathrm{R}^{2}$ uses regression to determine the fit between two sets of variables and indicates the strength of the relationship between the variables. $R^{2}$ values typically range between 0 and 1 , with values closer to 1 indicating a stronger relationship. $R 2$ is measured using the formula:

$$
\mathrm{R}^{2}=\frac{\text { Regression sum of squares (SSR) }}{\text { Total sum of squares (SSTO) }}
$$

where SSR is a measure of the sum of the squared differences between the regression line and the mean line of data-points and SSTO is a measure of the squared differences between data-points and their mean line. The process for estimating $\mathrm{R}^{2}$ involves first plotting the two variables whose relationship is being tested on the $y$ and $x$ axes, with the dependent variable on the $y$-axis and the independent variable on the $\mathrm{x}$ axis. The best fit or regression line is then fitted to the datapoints, followed by a horizontal line representing the mean of the dependent variable (y). SSR and SSTO are then calculated based on the original data points and points on the mean and regression lines to allow the calculation of R2 (Penn State Eberly College of Science, n.d.).Table VI shows a rating scale for the $\mathrm{R}^{2}$ values for ranking the strengths of the correlations between the Mineral Reserves and modifying factors. Tables VII and VIII provide a summary of $\mathrm{R}^{2}$ values between reported modifying factors and declared Mineral Reserves. Tables VII and VIII show that the reported Mineral Reserves of South African gold and platinum mining companies

Table VI

Rating scale for $\mathbf{R}^{\mathbf{2}}$ values for the linear relationship between Mineral Reserves and modifying factors (Maseko, 2018)

\begin{tabular}{|l|c|c|c|}
\hline Coefficient of determination $\left(\mathbf{R}^{2}\right)$ & $0-0.4$ & $0.4-0.6$ & $0.6-1.0$ \\
\hline $\begin{array}{l}\text { Correlation rating } \\
\text { Colour }\end{array}$ & $\begin{array}{c}\text { Poor } \\
\text { Red }\end{array}$ & $\begin{array}{c}\text { Moderate } \\
\text { Orange }\end{array}$ & $\begin{array}{c}\text { Good } \\
\text { Green }\end{array}$ \\
\hline
\end{tabular}

\begin{tabular}{|c|c|c|c|c|c|c|c|c|c|}
\hline \multicolumn{10}{|c|}{$\begin{array}{l}\text { Table VII } \\
\mathbf{R}^{2} \text { values for reporte } \\
\text { mining companies in }\end{array}$} \\
\hline \multicolumn{2}{|c|}{ Mineral Reserves } & \multicolumn{8}{|c|}{ Moditying Factor $R^{2}$ Values } \\
\hline Company & Operation & $\begin{array}{l}\text { Gold } \\
\text { Price }\end{array}$ & $\begin{array}{l}\text { Cut-oft } \\
\text { grade }\end{array}$ & $\begin{array}{l}\text { Mine Call } \\
\text { Factor }\end{array}$ & $\begin{array}{l}\text { Metallurgical } \\
\text { Recovery }\end{array}$ & $\begin{array}{l}\text { Stoplang } \\
\text { woth }\end{array}$ & Dilution & $\begin{array}{l}\text { Cut-oft } \\
\text { Cost }\end{array}$ & $\begin{array}{l}\text { Mining } \\
\text { Loss }\end{array}$ \\
\hline \multirow{9}{*}{$\begin{array}{l}\text { Anglo } \\
\text { Gold } \\
\text { Ashans }\end{array}$} & Kopanang & 0.93 & 000 & 0.05 & 0.52 & 0.80 & 0.03 & NR & NR \\
\hline & Moob Khotsong & 0.05 & 0.07 & 0.61 & 0.01 & 0.15 & 0.08 & NR & NR \\
\hline & Mponeng & 0.56 & 0.04 & 0.57 & 0.07 & 0.51 & 0.01 & NR & NR \\
\hline & Tau Tons & 0.86 & 0.16 & 0.57 & 0.59 & 0.61 & 0.23 & NR & NR \\
\hline & Grost Noligwa & 0.84 & 0.00 & 0.94 & 0.59 & 0.58 & 0.13 & NR & NR \\
\hline & Sanika & 0.45 & 0.04 & 007 & 001 & 004 & 0.00 & NR & NR \\
\hline & Tau Lekoa & 0.49 & 0.00 & 0.09 & 0.71 & 0.27 & 0.26 & NR & NR \\
\hline & Surtace Operations & 0.59 & 0.71 & NR & 0.58 & N/A & NAA & NR & NAA \\
\hline & Average & 0.60 & 0.13 & 0.41 & 0.39 & 0.42 & 0.11 & NR & NR \\
\hline \multirow{15}{*}{$\begin{array}{l}\text { Marmony } \\
\text { cold }\end{array}$} & Dornkop & 0.54 & 0.49 & 0.29 & 0.12 & 0.03 & NR & 0.19 & NR \\
\hline & Kusasslothu & 0.59 & 0.90 & 0.53 & 0.65 & 007 & NR & 0.97 & NR \\
\hline & Target 1 & 0.85 & 0.32 & 0.14 & 0.33 & NA & 0.06 & 0.63 & NR \\
\hline & Taxget 3 & 0.58 & 0.08 & 0.00 & 0.29 & 0.28 & NR & 0.17 & NR \\
\hline & Tshepong & 0.72 & 0.00 & 0.97 & 0.79 & 0.88 & NR & 0.06 & NR \\
\hline & Phatisa & 0.54 & 0.59 & 0.25 & 0.02 & 0.42 & NR & 0.75 & NR \\
\hline & Bambanani & 0.88 & 0.01 & 0.37 & 0.25 & 0.00 & NR & 0.73 & NR \\
\hline & Unisel & 0.82 & 0.23 & 0.69 & 0.48 & 0.44 & NR & 0.67 & NR \\
\hline & Masimong & 0.61 & 006 & 0.81 & 0.00 & 061 & NR & 0.76 & NR \\
\hline & Joet & 0.75 & 0.75 & 0.06 & 0.07 & 0.58 & NR & 0.25 & NR \\
\hline & $\begin{array}{l}\text { Freo State Surtace } \\
\text { Operations }\end{array}$ & 0.51 & 0.35 & 000 & 0.03 & NAA & NR & 0.47 & NR \\
\hline & Kalgold & 0.23 & 000 & 0.00 & 0.02 & N/A & 0.46 & 000 & NR \\
\hline & Evandor & 0.06 & NR & 0.47 & 0.31 & 0.17 & NR & NR & NR \\
\hline & Merriosprit & 0.68 & NR & 0.22 & 0.98 & 0.56 & NR & NR & NR \\
\hline & Average & 0.60 & 0.32 & 0.30 & 0.31 & 0.37 & 0.26 & 0.47 & NR \\
\hline \multirow{4}{*}{$\begin{array}{l}\text { Gold } \\
\text { Flods }\end{array}$} & South Deep & 0.56 & 0.73 & 0.02 & 0.44 & NR & 0.22 & NR & 0.50 \\
\hline & Beotrix Goid Mine & 0.60 & 0.25 & 0.83 & 0.01 & NR & 0.01 & NR & 0.83 \\
\hline & $\begin{array}{l}\text { Koot-Oriofontoin } \\
\text { Complex }\end{array}$ & 0.67 & 005 & 0.10 & 0,00 & NR & 0.84 & NR & 0.10 \\
\hline & Average & 0.61 & 0.38 & 0.32 & 0.15 & NR & 0.36 & NR & 0.48 \\
\hline \multirow{5}{*}{$\begin{array}{l}\text { Stbanyo } \\
\text { Gold }\end{array}$} & Beotrix & 0.18 & 0.13 & 0.55 & 000 & 0.12 & NR & NR & NR \\
\hline & Driofontein & 0.33 & 0.54 & 0.68 & 0.00 & 0.10 & NR & NR & NR \\
\hline & Koot & 0.41 & 003 & 000 & 0.51 & 0.67 & NR & NR & NR \\
\hline & Cooke Operations & 0.95 & 0.29 & 0.82 & 0.17 & 0.03 & NR & NR & NR \\
\hline & Average & 0.47 & 0.25 & 0.51 & 0.17 & 0.23 & NR & NR & NR \\
\hline \multicolumn{2}{|c|}{ OVERALL AVERAGE } & 0.57 & 0.27 & 0.39 & 0.25 & 0.94 & 0.24 & 0.47 & 0.48 \\
\hline
\end{tabular}




\section{An empirical long-term commodity price range for Mineral Reserve declarations}

\begin{tabular}{|c|c|c|c|c|c|c|c|c|c|c|}
\hline \multicolumn{11}{|c|}{$\begin{array}{l}\text { Table VIII } \\
\mathbf{R}^{2} \text { values for reported Mineral Reserves and modifying factors for major platinum } \\
\text { mining companies in South Africa between } 2000 \text { and } 2016 \text { (Maseko, 2018) }\end{array}$} \\
\hline \multicolumn{2}{|c|}{ Mineral Reserves } & \multicolumn{9}{|c|}{ Modifying Factor $\mathrm{R}^{2}$ Values } \\
\hline Company & Operation/Reef & $\begin{array}{l}\text { Platinum } \\
\text { Price }\end{array}$ & $\begin{array}{l}\text { Palladium } \\
\text { Price }\end{array}$ & $\begin{array}{l}\text { Rhodium } \\
\text { Price }\end{array}$ & $\begin{array}{l}\text { Gold } \\
\text { Price }\end{array}$ & $\begin{array}{l}\text { Ruthenium } \\
\text { Price }\end{array}$ & $\begin{array}{c}\text { Iridium } \\
\text { Price }\end{array}$ & Dilution & $\begin{array}{c}\text { Mining } \\
\text { Loss }\end{array}$ & Paylimit \\
\hline \multirow{5}{*}{ Northam } & $\begin{array}{l}\text { Zondereinde } \\
\text { mine }\end{array}$ & 0.09 & NR & NR & NR & NR & NR & NR & NR & NR \\
\hline & Dwaalkop & 0.00 & NR & NR & NR & NR & NR & NR & NR & NR \\
\hline & $\begin{array}{l}\text { Booysendal } \\
\text { North mine }\end{array}$ & 0.72 & NR & NR & NR & NR & NR & NR & NR & NR \\
\hline & Pandora & 0.46 & NR & NR & NR & NR & NR & NR & NR & NR \\
\hline & Average & 0.32 & NR & NR & NR & NR & NR & NR & NR & NR \\
\hline \multirow{4}{*}{ Lonmin } & Marikana & 0.93 & 0.79 & 0.03 & 0.78 & 0.00 & 0.96 & 0.07 & 0.49 & NR \\
\hline & Pandora & 0.74 & 0.66 & 0.17 & 0.79 & 0.84 & 0.76 & 0.22 & 0.56 & NR \\
\hline & Limpopo & 0.20 & 0.13 & 0.04 & 0.11 & 0.45 & 0.34 & 0.97 & 0.97 & NR \\
\hline & Average & 0.62 & 0.53 & 0.08 & 0.56 & 0.43 & 0.69 & 0.42 & 0.67 & NR \\
\hline \multirow{6}{*}{ Implats } & Impala & 0.04 & 0.01 & 0.03 & NR & NR & NR & NR & NR & NR \\
\hline & Marula & 0.32 & 0.06 & 0.05 & NR & NR & NR & NR & NR & NR \\
\hline & Two Rivers & 0.25 & 0.02 & 0.01 & NR & NR & NR & NR & NR & NR \\
\hline & Zimplats & 0.37 & 0.33 & 0.17 & NR & NR & NR & NR & NR & NR \\
\hline & Mimosa & 0.02 & 0.23 & 0.34 & NR & NR & NR & NR & NR & NR \\
\hline & Average & 0.20 & 0.13 & 0.12 & NR & NR & NR & NR & NR & NR \\
\hline \multirow{5}{*}{ Amplats } & Merensky & NR & NR & NR & NR & NR & NR & NR & NR & 0.19 \\
\hline & UG2 & NR & NR & NR & NR & NR & NR & NR & NR & 0.48 \\
\hline & Platreef & NR & NR & NR & NR & NR & NR & NR & NR & 0.55 \\
\hline & $\begin{array}{l}\text { Main Sulphide } \\
\text { Zone }\end{array}$ & NR & NR & NR & NR & NR & NR & NR & NR & NR \\
\hline & Average & NR & NR & NR & NR & NR & NR & NR & NR & 0.41 \\
\hline \multirow{2}{*}{\multicolumn{2}{|c|}{ OVERALL AVERAGE }} & 0.38 & 0.33 & 0.10 & 0.56 & 0.43 & 0.69 & \multirow{2}{*}{0.42} & \multirow{2}{*}{0.67} & \multirow{2}{*}{0.41} \\
\hline & & & & & & & & & & \\
\hline
\end{tabular}

between 2000 and 2016 were mostly sensitive to long-term commodity prices as the $\mathrm{R}^{2}$ (on average) values are generally higher than those of the other modifying factors.

\section{Impairments and ideal range for long-term commodity prices}

An assessment of the non-financial asset impairments of South African gold and platinum mining companies from 2000 to 2016 gives an indication of the relationship between asset carrying values as represented by long-term commodity prices and recoverable values as represented by prevailing spot prices.

The major South African gold mining companies mostly assumed rand-denominated long-term gold prices lower than spot prices between 2000 and 2016. However, these companies recorded significant non-financial asset impairments in this period, as shown in Table IX. This indicates that having a conservative view on long-term prices does not prevent the incurring of impairments. However, Figure 10 shows that when long-term gold price assumptions of the South African gold mining companies were within $\pm 5 \%$ of spot prices, then minimal impairments were recorded. The majority of impairments were recorded outside the $\pm 5 \%$ longterm gold price to spot price range, which suggests that this could be an ideal long-term gold price assumption range in Mineral Reserve declarations for South African gold mining companies.

Among South Africa's major platinum mining companies, Implats and Lonmin have on average assumed long-term platinum prices that were higher than spot prices between
2003 and 2016, as shown in Table X. Northam assumed conservative long-term platinum prices (relative to spot prices) in the earlier part of the period and higher prices in the latter part, resulting in an average variance of zero over the period. Since Amplats did not report its assumed longterm platinum price, a comparison with spot prices could not be undertaken. The major South African platinum mining companies have also recorded significant non-financial asset impairments in the period from 2000 to 2016, with Northam recording the least impairments (Table $\mathrm{X}$ ). Figure 11 shows that of the several impairments recorded by the major South African platinum mining companies from 2000 to 2016, very few occurred in the $\pm 5 \%$ long-term platinum price to spot price ratio range. The historical long-term commodity prices used for impairment testing purposes would have been in line with the long-term prices used for Mineral Reserve estimation. The use of long-term commodity prices that were within $5 \%$ of prevailing spot prices resulted in reporting of ounces that were economically mineable (Mineral Reserves) under the prevailing conditions, as evidenced by the limited number of impairments incurred within this commodity price range. This suggests that this range is ideal for long-term platinum prices to minimize impairments for South African platinum mining companies.

\section{Conclusions}

This study evaluated the impact of modifying factors on the Mineral Reserve estimates reported by the major South African gold and platinum mining companies from 2000 to 2016. Among the modifying factors used in Mineral Reserve 


\section{An empirical long-term commodity price range for Mineral Reserve declarations}

\begin{tabular}{|c|c|c|c|c|c|c|c|c|c|c|c|c|c|}
\hline \multicolumn{14}{|c|}{$\begin{array}{l}\text { Table IX } \\
\text { Long-term gold prices and impairments for major gold mining companies in South Africa between } 2000 \\
\text { and } 2016 \text { (sources: SNL Metals \& Mining, n.d; AngloGold Ashanti, 2000-2016; Harmony Gold, 2000-2016; } \\
\text { Gold Fields, 2000-2016; Sibanye Gold, 2013-2016) }\end{array}$} \\
\hline \multirow[b]{2}{*}{ rear } & \multirow[b]{2}{*}{$\begin{array}{c}\text { Spot } \\
\text { Gold } \\
\text { Price } \\
\text { (ZAR/kg) }\end{array}$} & \multicolumn{3}{|c|}{ Anglo Gold Ashanti } & \multicolumn{3}{|c|}{ Harmony Gold } & \multicolumn{3}{|c|}{ Gold Fields } & \multicolumn{3}{|c|}{ Sibanye Gold } \\
\hline & & $\begin{array}{l}\text { Long- } \\
\text { Term } \\
\text { Gold } \\
\text { Price } \\
\text { (ZAR/kg) }\end{array}$ & $\begin{array}{l}\text { Long- } \\
\text { Term } \\
\text { Gold } \\
\text { Price } \\
\text { Relative } \\
\text { to Spot } \\
\text { Price } \\
(\%)\end{array}$ & $\begin{array}{c}\text { Non- } \\
\text { Financial } \\
\text { Asset } \\
\text { Impairment } \\
\text { (ZARm) }\end{array}$ & $\begin{array}{l}\text { Long- } \\
\text { Term } \\
\text { Gold } \\
\text { Price } \\
\text { (ZAR/kg) }\end{array}$ & $\begin{array}{l}\text { Long- } \\
\text { Term } \\
\text { Gold } \\
\text { Price } \\
\text { Relative } \\
\text { to Spot } \\
\text { Price } \\
\text { (\%) }\end{array}$ & $\begin{array}{c}\text { Non- } \\
\text { Financial } \\
\text { Asset } \\
\text { Impairment } \\
\text { (ZARm) }\end{array}$ & $\begin{array}{l}\text { Long- } \\
\text { Term } \\
\text { Gold } \\
\text { Price } \\
\text { (ZAR/kg) }\end{array}$ & $\begin{array}{l}\text { Long- } \\
\text { Term } \\
\text { Gold } \\
\text { Price } \\
\text { Relative } \\
\text { to Spot } \\
\text { Price } \\
\text { (\%) }\end{array}$ & $\begin{array}{c}\text { Non- } \\
\text { Financial } \\
\text { Asset } \\
\text { Impairment } \\
\text { (ZARm) }\end{array}$ & $\begin{array}{l}\text { Long- } \\
\text { Term } \\
\text { Gold } \\
\text { Price } \\
\text { (ZAR/kg) }\end{array}$ & $\begin{array}{l}\text { Long- } \\
\text { Term } \\
\text { Gold } \\
\text { Price } \\
\text { Relative } \\
\text { to Spot } \\
\text { Price } \\
\text { (\%) }\end{array}$ & $\begin{array}{c}\text { Non- } \\
\text { Financial } \\
\text { Asset } \\
\text { Impairment } \\
\text { (ZARm) }\end{array}$ \\
\hline 2016 & 590506 & 530000 & $(10) \%$ & 42 & 475107 & $(20) \%$ & (43) & 550000 & $(7) \%$ & 1080 & 490000 & $(17) \%$ & 1172 \\
\hline 2015 & 475767 & 431000 & $(9) \%$ & 65 & 450026 & $(5) \%$ & 3471 & 500000 & $5 \%$ & 861 & 430000 & $(10) \%$ & 0 \\
\hline 2014 & 441465 & 398452 & $(10) \%$ & 6 & 425064 & (4) $\%$ & 1439 & 400000 & $(9) \%$ & 141 & 420000 & $(5) \%$ & (319) \\
\hline 2013 & 437828 & 360252 & (18)\% $\%$ & $\begin{array}{l}3109 \\
302 \\
\end{array}$ & 400148 & $(9) \%$ & 2735 & 400000 & $(9) \%$ & $\begin{array}{l}6778 \\
719 \\
\end{array}$ & 410000 & $\frac{6}{(6) \%}$ & 821 \\
\hline & $\begin{array}{l}440417 \\
367051\end{array}$ & 290064 & $(34)$ & 392 & 339 & $\frac{23}{21}$ & $\frac{(60)}{264}$ & 380 & $(14$ & 718 & 380000 & (14)\% & 0 \\
\hline$\frac{2011}{2010}$ & 3670 & 269841 & $(26)$ & $\frac{88}{634}$ & $\frac{279}{250}$ & $\left.\frac{(24}{12}\right)$ & 264 & 310 & $(16)$ & 3 & N/A & & N/A \\
\hline 2010 & 288628 & $\frac{238028}{22767}$ & (18)\% & $\begin{array}{r}634 \\
61131 \\
\end{array}$ & $\frac{250}{224 c}$ & & 331 & $\frac{265}{230}$ & & & & & $\frac{N / A}{N / A}$ \\
\hline 2009 & 265204 & 227627 & (14)\% $\%$ & $(5113)$ & $224 \mathrm{~S}$ & & 546 & 230 & $(13) \%$ & 1210 & & & N/A \\
\hline 2008 & 231573 & $\frac{200698}{148536}$ & $\frac{(13) \%}{66 \%}$ & 14793 & $\begin{array}{l}179883 \\
115022\end{array}$ & $\frac{(22) \%}{(27) \%}$ & 316 & $\frac{150}{100}$ & $(35) \%$ & $\frac{51}{3}$ & & & N/A \\
\hline$\frac{2007}{2006}$ & $\frac{157820}{13187}$ & $\frac{148536}{114939}$ & $\frac{(6) \%}{(13) \%}$ & $\frac{6}{44}$ & $\begin{array}{l}115022 \\
104972\end{array}$ & $\frac{(27) \%}{(20) \%}$ & $\frac{(134)}{(216)}$ & $\frac{100000}{92000}$ & $\frac{(37) \%}{30 \% \%}$ & $\frac{3}{0}$ & $\frac{A}{A}$ & $\frac{N \text { N/A }}{\text { N/A }}$ & $\frac{N / A}{N / A}$ \\
\hline$\frac{2006}{2005}$ & $\frac{131187}{91065}$ & $\frac{114999}{86807}$ & $\frac{(13) \%}{(5) \%}$ & $\frac{44}{300}$ & $\frac{104922}{91996}$ & $\frac{(20) \%}{1 \%}$ & $\frac{(216)}{1513}$ & $92 \mathrm{C}$ & $1 \%$ & 261 & $\frac{a}{4}$ & $\frac{a}{4}$ & $\frac{N / A}{N / A}$ \\
\hline 2004 & 85121 & 94764 & $11 \%$ & $\frac{300}{8}$ & 91996 & $8 \%$ & & 90000 & $6 \%$ & 426 & $N / / A$ & $N / A$ & \\
\hline 2003 & 88522 & 78769 & $(11) \%$ & 327 & 92948 & $5 \%$ & 886 & 95000 & $7 \%$ & $\frac{420}{0}$ & $N / / A$ & $N / A$ & N/A \\
\hline 2002 & 105194 & 94041 & $(11) \%$ & 0 & 94845 & $(10) \%$ & 457 & 951 & $(10) \%$ & 0 & $N / A$ & $N / A$ & $\mathrm{~N} / \mathrm{A}$ \\
\hline 2001 & 75056 & 71262 & $(5) \%$ & 1394 & 67388 & $(10) \%$ & 225 & 69992 & $\frac{107 \%}{(7) \%}$ & 2121 & $N / A$ & N/A & $\mathrm{N} / \mathrm{A}$ \\
\hline 2000 & & NR & NR & 2632 & 60033 & (4) $\%$ & 0 & NR & $\mathrm{NR}$ & 100 & $\mathrm{~N} / \mathrm{A}$ & N/A & N/A \\
\hline \multicolumn{2}{|c|}{ TOTALIAVERAGE } & & $(12) \%$ & 18727 & & $(111) \%$ & 11749 & & $(11) \%$ & 14076 & & $(10) \%$ & 1674 \\
\hline
\end{tabular}
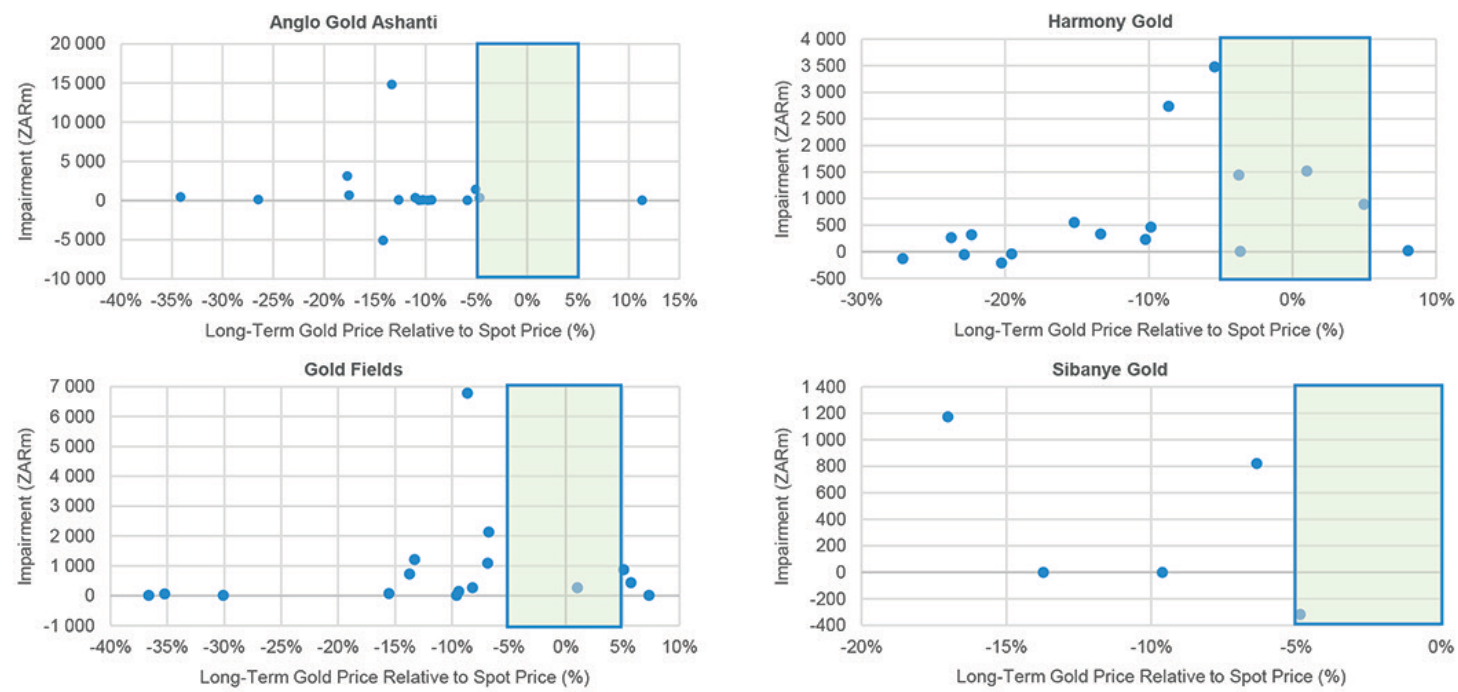

Figure 10-Long-term gold prices and gold mining company impairments (sources: SNL Metals \& Mining, n.d.; AngloGold Ashanti, 2000-2016; Harmony Gold, 2000-2016; Gold Fields, 2000-2016; Sibanye Gold, 2013-2016)

estimation, the Mineral Reserves of South African gold and platinum mining companies appeared to have been most sensitive to changes in long-term gold and platinum prices between 2000 and 2016. The study further noted that South Africa's major gold mining companies consistently reported the long-term gold prices used in their Mineral Reserves from 2001, a year after the introduction of the SAMREC Code. Mineral Reserve reporting by South Africa's major platinum mining companies was less detailed than that by gold mining companies. The reporting of long-term platinum prices used in Mineral Reserve estimation by platinum mining companies only started between 2003 and 2005. Amplats did not report its long-term platinum prices over the period between 2000 and 2016. The South African gold mining companies reported long-term rand-denominated gold prices that were lower than prevailing spot prices over the 2000 to 2016 period. The platinum mining companies, however, reported long-term platinum price assumptions that were mostly higher than prevailing spot prices. Therefore, South African platinum mining companies were most likely to have reported ounces that were uneconomic as part of their Mineral Reserves and would have been more prone to impairments between 2000 and 2016. An assessment of long-term gold and platinum prices relative to historical spot prices and their impact on the number of non-financial asset impairments recorded by South Africa's gold and platinum mining companies revealed 


\section{An empirical long-term commodity price range for Mineral Reserve declarations}

\begin{tabular}{|c|c|c|c|c|c|c|c|c|c|c|c|c|c|}
\hline \multicolumn{14}{|c|}{$\begin{array}{l}\text { Long-term platinum prices and impairments for major platinum mining companies in South Africa between } \\
2000 \text { and } 2016 \text { (sources: SNL Metals \& Mining, n.d.; Impala Platinum Holdings, 2000-2016; Northam Platinum, } \\
\text { 2000-2016; Lonmin plc, 2000-2016; Anglo American Platinum, 2000-2016; Sibanye, 2013-2016) }\end{array}$} \\
\hline \multirow[b]{2}{*}{ Year } & \multirow[b]{2}{*}{$\begin{array}{c}\text { Spot } \\
\text { Platinum } \\
\text { Price } \\
\text { (ZAR/oz) }\end{array}$} & \multicolumn{3}{|c|}{ Impala Platinum } & \multicolumn{3}{|c|}{ Northam Platinum } & \multicolumn{3}{|c|}{ Lonmin Plc } & \multicolumn{3}{|c|}{ Anglo American Platinum } \\
\hline & & $\begin{array}{l}\text { Long- } \\
\text { Term } \\
\text { Platinum } \\
\text { Price } \\
\text { (ZAR/oz) }\end{array}$ & $\begin{array}{l}\text { Long- } \\
\text { Term } \\
\text { Platinum } \\
\text { Price } \\
\text { Relative } \\
\text { to Spot } \\
\text { Price } \\
\text { (\%) }\end{array}$ & $\begin{array}{c}\text { Non- } \\
\text { Financial } \\
\text { Asset } \\
\text { Impairment } \\
\text { (ZARm) }\end{array}$ & $\begin{array}{l}\text { Long- } \\
\text { Term } \\
\text { Platinum } \\
\text { Price } \\
\text { (ZAR/oz) }\end{array}$ & $\begin{array}{l}\text { Long- } \\
\text { Term } \\
\text { Platinum } \\
\text { Price } \\
\text { Relative } \\
\text { to Spot } \\
\text { Price } \\
\text { (\%) }\end{array}$ & $\begin{array}{c}\text { Non- } \\
\text { Financial } \\
\text { Asset } \\
\text { Impairment } \\
\text { (ZARm) }\end{array}$ & $\begin{array}{l}\text { Long- } \\
\text { Term } \\
\text { Platinum } \\
\text { Price } \\
\text { (ZAR/oz) }\end{array}$ & $\begin{array}{l}\text { Long- } \\
\text { Term } \\
\text { Platinum } \\
\text { Price } \\
\text { Relative } \\
\text { to Spot } \\
\text { Price } \\
(\%)\end{array}$ & $\begin{array}{c}\text { Non- } \\
\text { Financial } \\
\text { Asset } \\
\text { Impairment } \\
\text { (ZARm) }\end{array}$ & $\begin{array}{l}\text { Long- } \\
\text { Term } \\
\text { Platinum } \\
\text { Price } \\
\text { (ZAR/oz) }\end{array}$ & $\begin{array}{l}\text { Long- } \\
\text { Term } \\
\text { Platinum } \\
\text { Price } \\
\text { Relative } \\
\text { to Spot } \\
\text { Price } \\
(\%)\end{array}$ & $\begin{array}{c}\text { Non- } \\
\text { Financial } \\
\text { Asset } \\
\text { Impairment } \\
\text { (ZARm) }\end{array}$ \\
\hline 2016 & 14525 & 18648 & $28 \%$ & 257 & 20291 & $40 \%$ & (14) & 20729 & $43 \%$ & 4593 & NR & NR & 22 \\
\hline 2015 & 13421 & 17718 & $32 \%$ & 5847 & 19357 & $44 \%$ & 264 & 18632 & $39 \%$ & 24493 & NR & NR & 10242 \\
\hline 2014 & 15009 & 26760 & $78 \%$ & 1000 & 13455 & (10)\% & 0 & 16785 & $12 \%$ & 0 & NR & NR & 480 \\
\hline 2013 & 14339 & 18778 & $31 \%$ & 0 & 15925 & $11 \%$ & 0 & 16785 & $17 \%$ & 0 & NR & NR & 833 \\
\hline 2012 & 12720 & 16080 & $26 \%$ & 0 & 11963 & (6)\% & 32 & 14875 & $17 \%$ & 4258 & NR & NR & 0 \\
\hline 2011 & 12488 & 22560 & $81 \%$ & 0 & 12866 & $3 \%$ & 0 & 15200 & $22 \%$ & 14 & NR & NR & 0 \\
\hline 2010 & 11792 & 27716 & $135 \%$ & 0 & 12360 & $5 \%$ & 0 & 14904 & $26 \%$ & 89 & NR & NR & 0 \\
\hline 2009 & 10211 & 20879 & $104 \%$ & 0 & 9450 & $(7) \%$ & 17 & 14400 & $41 \%$ & 0 & NR & NR & 0 \\
\hline 2008 & 12980 & 24083 & $86 \%$ & 108 & 14391 & $11 \%$ & 0 & 12000 & (8)\% & 715 & NR & NR & 209 \\
\hline 2007 & 9192 & 11085 & $21 \%$ & 0 & 6670 & (27)\% & 0 & 9208 & $0 \%$ & 0 & NR & NR & 0 \\
\hline 2006 & 7733 & 7850 & $2 \%$ & -583 & 5850 & (24)\% & 0 & 7700 & (0)\% & 0 & NR & NR & 0 \\
\hline 2005 & 5705 & 6700 & $17 \%$ & 1034 & 4950 & (13)\% & 0 & 4940 & (13)\% & 0 & NR & NR & 0 \\
\hline 2004 & 5464 & 6100 & $12 \%$ & 0 & 4347 & $(20) \%$ & 0 & NR & N/A & 0 & NR & NR & 0 \\
\hline 2003 & 5233 & 6100 & $17 \%$ & 0 & 5004 & (4)\% & 0 & NR & NR & 0 & NR & NR & 0 \\
\hline 2002 & 5688 & NR & NR & 0 & NR & NR & 11 & NR & NR & & NR & NR & 0 \\
\hline 2001 & 4557 & NR & NR & 0 & NR & NR & 11 & NR & NR & 105 & NR & NR & 0 \\
\hline 2000 & 3780 & NR & NR & 0 & NR & NR & 0 & NR & NR & 0 & NR & NR & \\
\hline \multicolumn{2}{|c|}{ TOTALAAVERAGE } & & $48 \%$ & 7663 & & $0 \%$ & 321 & & $16 \%$ & 34267 & & & 11786 \\
\hline
\end{tabular}
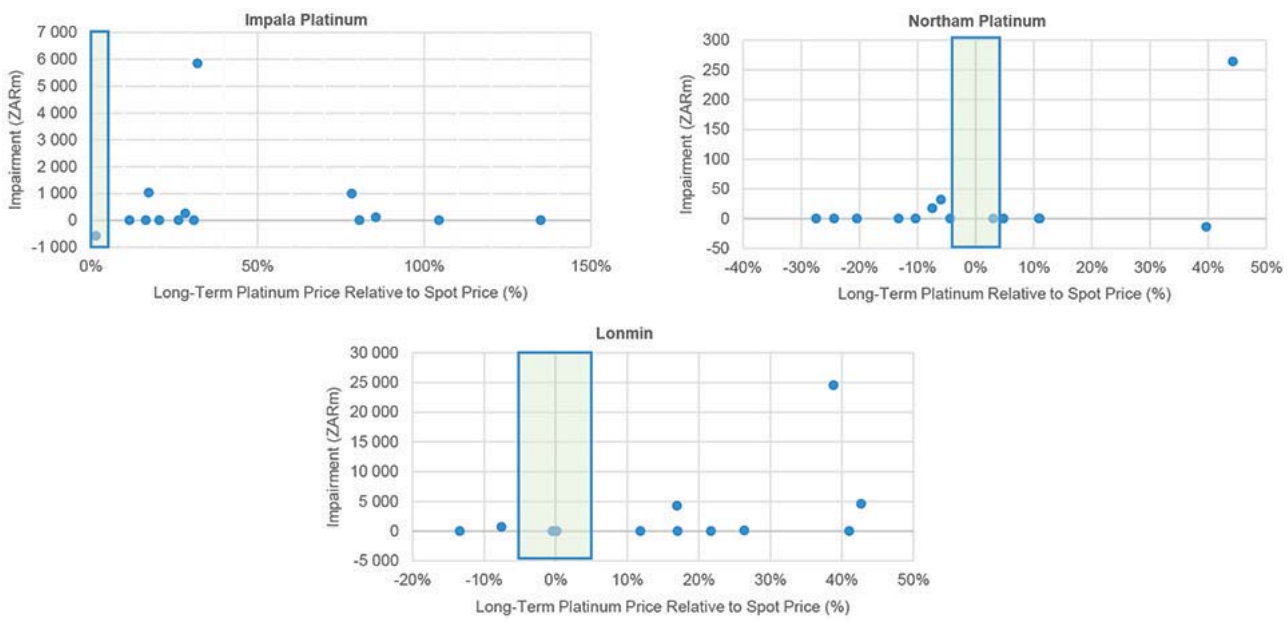

Figure 11-Long-term platinum prices and platinum mining company impairments (ources: SNL Metals \& Mining, n.d.; Impala Platinum Holdings, 20002016; Northam Platinum, (2000-2016; Lonmin plc, 2000-2016)

that the least number of impairments were recorded when long-term commodity prices were within $\pm 5 \%$ of prevailing spot prices. This suggests that if South Africa's gold and platinum mining companies keep their long-term commodity prices within $\pm 5 \%$ of rand-denominated spot prices, it could result in more reliable Mineral Reserve estimates, which could clearly demonstrate economic viability as evidenced by a potentially limited number of impairments incurred in the future.

\section{Acknowledgments}

The work reported in this paper is part of an MSc research study in the School of Mining Engineering at the University of the Witwatersrand.

\section{References}

ANGLo AmericAn PLC. 2000. Annual Report 2000. http://www.sharedata.co.za/Data/000238/pdfs/ANGLO_ar_00.pdf [accessed 14 October 2017].

ANGLo AmERICAN PLC. 2002. Annual Report 2002. https://core.ac.uk/download/pdf/33158338.pdf [Accessed 14 October 2017].

Anglo American PLc. 2003. Annual Report 2003.

http://www.angloamerican.com/ /media/Files/A/Anglo-American-PLCV2/investors/a-reports/2004rep/annual_review_2003.pdf [Accessed 14 October 2017].

Anglo American PLc. 2004. Annual Report 2004. http://china.angloamerican.com/ /media/Files/A/Anglo-AmericanChina/reports-and-publications/2004/annual-report-2004.pdf [accessed 14 October 2017].

Anglo American PLc. 2005. Annual Report 2005. http://china.angloamerican.com/ /media/Files/A/Anglo-American- 


\section{An empirical long-term commodity price range for Mineral Reserve declarations}

China/reports-and-publications/2005/angloamericanreport05.pdf [accessed 14 October 2017].

Anglo Platinum Limited. 2006. Annual Report 2006. http://www.angloamericanplatinum.com/ /media/Files/A/AngloAmerican-Platinum/annual-reports/2006.pdf [accessed 14 October 2017].

Anglo Platinum Limited. 2007. Annual Report 2007. http://www.angloamericanplatinum.com/ /media/Files/A/AngloAmerican-Platinum/annual-reports/2007.pdf [accessed 14 October 2017].

Anglo Platinum Limited. 2008. Annual Report 2008. http://www.angloamericanplatinum.com/ /media/Files/A/AngloAmerican-Platinum/annual-reports/2008.pdf [accessed 14 October 2017].

Anglo Platinum Limited. 2009. Annual Report 2009. http://www.angloamericanplatinum.com/ /media/Files/A/AngloAmerican-Platinum/annual-reports/ar2009.pdf [accessed 14 October 2017].

Anglo Platinum Limited. 2010. Annual Report 2010.

http://www.angloamerican.com/ /media/Files/A/Anglo-American-PLCV2/investors/a-reports/2011rep/angloplatinumltd_2010.pdf [accessed 14 October 2017].

Anglo American Platinum Limited. 2011. Integrated Annual Report 2011. http://www.angloamericanplatinum.com/ /media/Files/A/AngloAmerican-Platinum/AA\%20Plat\%20-

\%20INTEGRATED\%20ANNUAL\%20REPORT\%202011.pdf [accessed 14 October 2017]

Anglo American Platinum Limited. 2012. Annual Report 2012 http://www.angloamericanplatinum.com/ /media/Files/A/AngloAmerican-Platinum/annual-reports/anglo-american-platinum-ar-2012.pdf [accessed 14 October 2017].

Anglo American Platinum Limited. 2013. Ore Reserves and Mineral Resources Report 2013. http://www.angloamericanplatinum.com/ media/Files/A/Anglo-American-Platinum/documents/aap-rr-2013.pdf [accessed 14 October 2017].

Anglo American Platinum Limited. 2014. Ore Reserves and Mineral Resources Report 2014. http://www.angloamericanplatinum.com/ / media/Files/A/Anglo-American-Platinum/annual-reports/anglo-americanplatinum-r-and-r-2014.pdf [Accessed 14 October 2017].

Anglo American Platinum Limited. 2015. Ore Reserves and Mineral Resources Report 2015. http://www.angloamericanplatinum.com/ / media/Files/A/Anglo-American-Platinum/documents/amplats-mr-2015final.pdf [accessed 14 October 2017].

Anglo American Platinum Limited. 2016. Ore Reserves and Mineral Resources Report 2016. http://www.angloamericanplatinum.com/ / media/Files/A/Anglo-American-Platinum/annualreporting/downloads/ore-reserves-and-mineral-resources-2016.pdf [Accessed 14 October 2017].

AngloGold Limited. 2000. Form 20-F for the Financial Year Ended December 31, 2000. https://www.anglogoldashanti.com/investors/annualreports/form-20-f-form-6-k-us-gaap/ [accessed 14 October 2017].

ANGLoGold Limited. 2001. Form 20-F for the Financial Year Ended December 31, 2001. https://www.anglogoldashanti.com/investors/annualreports/form-20-f-form-6-k-us-gaap/ [accessed 14 October 2017].

ANGLOGold Limited. 2002. Supplementary Information: Ore Reserves and Mineral Resources 2002. https://www.anglogoldashanti.com/archive/miningreserves/Mineral\%20re source\%20and\%20ore\%20reserve\%20reports\%20(2002\%20\%202012).zip [accessed 14 October 2017].

ANGLoGold Limited. 2003. Supplementary Mineral Resource and Ore Reserve information 2003.

https://www.anglogoldashanti.com/archive/miningreserves/Mineral\%20re source\%20and\%20ore\%20reserve\%20reports\%20(2002\%20\%202012).zip [accessed 14 October 2017].

AngloGold Ashanti Limited. 2004. Supplementary Information: Mineral Resources and Ore Reserves 2004 https://www.anglogoldashanti.com/archive/miningreserves/Mineral\%20re source\%20and\%20ore\%20reserve\%20reports\%20(2002\%20\%202012).zip [accessed 14 October 2017].

ANGLoGold AshanTi Limited. 2005. Supplementary Information: Mineral Resources and Ore Reserves 2005

https://www.anglogoldashanti.com/archive/miningreserves/Mineral\%20re source $\% 20$ and\%20ore\%20reserve\%20reports\%20(2002\%20\%202012).zip [accessed 14 October 2017].

AngloGold Ashanti Limited. 2006. Supplementary Information: Mineral Resources and Ore Reserves 2006 https://www.anglogoldashanti.com/archive/miningreserves/Mineral\%20re source\%20and\%20ore\%20reserve\%20reports\%20(2002\%20\%202012).zip [accessed 14 October 2017].

AngloGold Ashanti Limited. 2007. Supplementary Information: Mineral Resources and Ore Reserves 2007. https://www.anglogoldashanti.com/ archive/miningreserves/Mineral\%20resource\%20and\%20ore\%20reserve\% 20reports\%20(2002\%20-\%202012).zip [accessed 14 October 2017].
AngloGold Ashanti Limited. 2008. Mineral Resource and Ore Reserve Report 2008. https://www.anglogoldashanti.com/archive/ miningreserves/Mineral\%20resource\%20and\%20ore\%20reserve\%20repo ts\%20(2002\%20-\%202012).zip [accessed 14 October 2017].

AngloGold Ashanti Limited. 2009. Mineral Resource and Ore Reserve Report 2009. https://www.anglogoldashanti.com/archive/miningreserves/ Mineral\%20resource\%20and\%20ore\%20reserve\%20reports\%20(2002\%2 0-\%202012).zip [accessed 14 October 2017].

AngloGold Ashanti Limited. 2010. Mineral Resource and Ore Reserve Report 2010. https://www.anglogoldashanti.com/archive/miningreserves/ Mineral\%20resource\%20and\%20ore\%20reserve\%20reports\%20(2002\%2 0-\%202012).zip [accessed 14 October 2017].

AngloGold Ashanti Limited. 2011. Mineral Resource and Ore Reserve Report 2011. https://www.anglogoldashanti.com/archive/miningreserves/ Mineral\%20resource\%20and\%20ore\%20reserve\%20reports\%20(2002\%2 0-\%202012).zip [accessed 14 October 2017].

AngloGold Ashanti Limited. 2012. Mineral Resource and Ore Reserve Report 2012. https://www.anglogoldashanti.com/archive/miningreserves/ Mineral\%20resource\%20and\%20ore\%20reserve\%20reports\%20(2002\%2 0-\%202012).zip [accessed 14 October 2017].

AngloGold Ashanti Limited. 2013. Mineral Resource and Ore Reserve Report 2013. https://thevault.exchange/?get_group_doc $=143 / 1502781082$ MineralResourceandOreReserveReport2013.pdf [accessed 14 October 2017].

AngloGold Ashanti Limited. 2014. Mineral Resource and Ore Reserve Report 2014. https://thevault.exchange/?get_group_doc=143/1502780826MineralResourceandOreReserveReport2014.pdf [accessed 14 October 2017].

AngloGold Ashanti Limited. 2015. Mineral Resource and Ore Reserve Report 2015. https://thevault.exchange/?get_group_doc $=143 / 1502780767$ MineralResourceandOreReserveReport2015.pdf [accessed 14 October 2017]

AngloGold Ashanti Limited. 2016. Mineral Resource and Ore Reserve Report 2016. https://thevault.exchange/?get group doc $=143 / 1502779473$ 2016MineralResourceandOreReserveReport.pdf [accessed 14 October 2017].

ApPLEYARD, G.R. 2001. An overview and outline, mineral resource and ore reserve estimation. The AusIMM Guide to Good Practice. Edwards, A.C. (ed.). Monograph 23, Australasian Institute of Mining and Metallurgy, Melbourne. pp. 3-12.

ApPLEYARD, G.R. AND SMith, C.L. 2001. Non-resource inputs to estimation of ore reserves - The modifying factors. Mineral Resource and Ore Reserve Estimation: the AusIMM Guide to Good Practice. Edwards, A.C. (ed.) Monograph 23, Australasian Institute of Mining and Metallurgy, Melbourne. pp. 325-332.

BAKER, C.K. and GiAcomo, S.M. 2001. Resources and Reserves Their uses and abuses by the equity markets. Mineral Resource and Ore Reserve Estimation: the AusIMM Guide to Good Practice Edwards, A.C., (e.d.)Monograph 23. The Australasian Institute of Mining and Metallurgy, Melbourne. pp.666-676.

BARCLAYS BANK PLC. 2014. Lonmin Plc Is this the time for change? - An equity research report by African Precious Metals. 7 November 2014

BARCLAYS BANK PLC. 2015. Built for today's environment An equity research report by African Precious Metals. 3 September 2015

Gold Fields Limited. 2001. Annual Report 2001. https://www.goldfields.com/pdf/investors/integrated-annualreports/2001/booklet.pdf [accessed 14 October 2017].

Gold Fields Limited. 2002. Annual Report 2002. https//www.goldfields.com/pdf/investors/integrated-annualreports/2002/booklet.pdf [accessed 14 October 2017].

Gold Fields Limited. 2003. Annual Report 2003. https://www.goldfields.com/pdf/investors/integrated-annualreports/2003/booklet.pdf [accessed 14 October 2017].

Gold Fields Limited. 2004. Annual Report 2004. https://www.goldfields.com/pdf/investors/integrated-annualreports/2004/booklet.pdf [accessed 14 October 2017].

Gold Fields Limited. 2005. Annual Report 2005. https://www.goldfields.com/pdf/investors/integrated-annualreports/2005/booklet.pdf [accessed 14 October 2017].

Gold Fields Limited. 2006. Annual Report 2006. https://www.goldfields.com/pdf/investors/integrated-annualreports/2006/booklet.pdf [accessed 14 October 2017].

Gold Fields Limited. 2007. Annual Report 2007. https://www.goldfields.com/pdf/investors/integrated-annualreports/2007/booklet.pdf [accessed 14 October 2017].

Gold Fields Limited. 2008. Annual Report 2008. https://www.goldfields.com/pdf/investors/integrated-annualreports/2008/iar-2008.pdf [accessed 14 October 2017]. 


\section{An empirical long-term commodity price range for Mineral Reserve declarations}

Gold Fields Limited. 2009. Annual Report 2009. https://www.goldfields.com/pdf/investors/integrated-annualreports/2009/iar-2009.pdf [accessed 14 October 2017].

Gold Fields Limited. 2010. Mineral Resources and Mineral Reserves 2010. https://www.goldfields.co.za/reports/annual_report_2010/minerals_overvi ew.php [accessed 14 October 2017].

Gold Fields Limited. 2011. Mineral Resources and Mineral Reserves 2011. https://www.goldfields.co.za/reports/ar_dec_2011/minerals/downloads_pd f.php [accessed 14 October 2017].

Gold Fields Limited. 2012. Mineral Resources and Mineral Reserves 2012. https://www.goldfields.com/pdf/investors/mineral-reserves-andresources-reports/2012/mrr-2012.pdf [accessed 14 October 2017].

Gold Fields Limited. 2013. Mineral Resources and Mineral Reserves 2013 https://www.goldfields.com/pdf/investors/mineral-reserves-andresources-reports/2013/mrr-2013.pdf [accessed 14 October 2017].

Gold Fields Limited. 2014. Mineral Resources and Mineral Reserves 2014. https://www.goldfields.com/pdf/investors/mineral-reserves-andresources-reports/2014/mrr-2014.pdf [accessed 14 October 2017].

Gold Fields Limited. 2015. Mineral Resources and Mineral Reserves 2015. https//www.goldfields.com/pdf/investors/mineral-reserves-and-resourcesreports/2015/mrr-2015.pdf [accessed 14 October 2017]

Gold Fields Limited. 2016. Mineral Resources and Mineral Reserves 2016. https://www.goldfields.com/pdf/investors/mineral-reserves-andresources-reports/2016/mrr-2016-hires.pdf [accessed 14 October 2017].

Harmony Gold Mining Company Limited. 2000a. Annual Report 2000. https://www.harmony.co.za/assets/investors/reporting/annualreports/harmony_ar2000.pdf [accessed 14 October 2017].

Harmony Gold Mining Company Limited. 2000b. Form 20-F for the fiscal year ended June 30, 2000. https://www.harmony.co.za/downloads/send/23form-20-f/368-form-20-f-2000 [accessed 14 October 2017].

Harmony Gold Mining Company Limited. 2001a. Annual Report 2001. https//www.harmony.co.za/assets/investors/reporting/annualreports/2001/landing.htm [accessed 14 October 2017].

Harmony Gold Mining Company Limited. 2001b. Form 20-F for the fiscal year ended June 30, 2001. https://www.harmony.co.za/downloads/send/23form-20-f/367-form-20-f-2001 [accessed 14 October 2017].

Harmony Gold Mining Company Limited. 2002. Annual Report 2002. https//www.harmony.co.za/assets/investors/reporting/annualreports/harmony_ar2002.pdf [accessed 14 October 2017].

HaRmony Gold Mining Company Limited. 2003. Annual Report 2003. https://www.harmony.co.za/assets/investors/reporting/annualreports/harmony_ar2003.pdf [accessed 14 October 2017].

HaRmony Gold Mining Company Limited. 2004. Annual Report 2004 https://www.harmony.co.za/assets/investors/reporting/annualreports/harmony ar2004.pdf [accessed 14 October 2017].

HaRmony Gold Mining Company Limited. 2005. Mineral Resources and Ore Reserves 2005. https//www.harmony.co.za/assets/investors/ reporting/annual-reports/2005/Harmony_ar2005_res.pdf [accessed 14 October 2017].

Harmony Gold Mining Company Limited. 2006. Annual Report 2006. https://www.harmony.co.za/assets/investors/reporting/annualreports/2006/files/Harmony_AR2006.pdf [accessed 14 October 2017]

Harmony Gold Mining Company Limited. 2007. Annual Report 2007. https://www.harmony.co.za/assets/investors/reporting/annualreports/2007/files/Harmony_AR07.pdf [Accessed 14 October 2017]

Harmony Gold Mining Company Limited. 2008. Annual Report 2008. https://www.harmony.co.za/assets/investors/reporting/annualreports/2008/files/Harmony_AR2008.pdf [accessed 14 October 2017].

Harmony Gold Mining Company Limited. 2009. Annual Report 2009. https://www.harmony.co.za/assets/investors/reporting/annualreports/2009/files/Harmony_AR09.pdf [accessed 14 October 2017].

Harmony Gold Mining Company Limited. 2010. Annual Report 2010. https://www.harmony.co.za/assets/investors/reporting/annualreports/2010/f/HAR_AR2010.pdf [accessed 14 October 2017].

HaRmony Gold Mining Company Limited. 2011. Annual Report 2011. http://www.financialresults.co.za/2011/harmony_ar2011/downloads/ha mony integrated ar2011.pdf [accessed 14 October 2017].

HaRmony Gold Mining Company Limited. 2012. Annual Report 2012. http://www.financialresults.co.za/2012/harmony_ar2012/integratedreport/downloads/Harmony\%20AR_Lo-Res_new.pdf [Accessed 14 October 2017]

Harmony Gold Mining Company Limited. 2013. Mineral Resources and Mineral Reserves 2013. http://www.financialresults.co.za/2013/harmony_ir2013/ harmony_mr2013/index.php [accessed 14 October 2017].

Harmony Gold Mining Company Limited. 2014. Form 20-F for the fiscal year ended June 30, 2014. https://www.harmony.co.za/downloads/send/23form-20-f/1038-2014-harmony-20f [accessed 14 October 2017].
Harmony Gold Mining Company Limited. 2015. Mineral IResources and Minera reserves 2015. http://www.har.co.za/15/download/HAR-RR15.pdf [accessed 14 October 2017].

Harmony Gold Mining Company Limited. 2016. Mineral Resources and Minera Reserves 2016. http://www.har.co.za/16/download/HAR-RR16.pdf [accessed 14 October 2017].

Impala Platinum Holdings Limited. 2000. Mineral Resources and Mineral Reserves 2000. http://implats-reports.co.za/reports/2000/pdfs/Impala_ plat.pdf [accessed 14 October 2017]

Impala Platinum Holdings Limited. 2001, Annual Report 2001, http://www.implats.co.za/pdf/annual-reports/archive/2001/implatsar2001.pdf [accessed 14 October 2017]

Impala Platinum Holdings Limited. 2002. Annual Report 2002. http://www.implats.co.za/pdf/annual-reports/archive/2002/implats ar2002.pdf [accessed 14 October 2017]

Impala Platinum Holdings Limited. 2003. Annual Report 2003. http://www.implats.co.za/pdf/annual-reports/archive/2003/implats ar2003.pdf [accessed 14 October 2017]

Impala Platinum Holdings Limited. 2004. Annual Report 2004. http://www.implats.co.za/pdf/annual-reports/archive/2004/implatsar2004.pdf [accessed 14 October 2017].

Impala Platinum Holdings Limited. 2005. Annual Report 2005. http://www.implats.co.za/pdf/annual-reports/archive/2005/implats ar2005.pdf [Accessed 14 October 2017].

Impala Platinum Holdings Limited. 2006. Annual Report 2006. http://implatsreports.co.za/reports/2006/default.htm [accessed 14 October 2017]

Impala Platinum Holdings Limited. 2007. Annual Report 2007. http://implatsreports.co.za/reports/2007/default.htm [accessed 14 October 2017]

Impala Platinum Holdings Limited. 2008. Implats Mineral Resource and Mineral Reserve Statement 2008. http://www.implats.co.za/pdf/annualreports/mr-mr-statement/2008/implats-mrmr-2008.pdf [Accessed 14 October 2017].

Impala Platinum Holdings Limited. 2009. Implats Mineral Resource and Mineral Reserve Statement 2009. http://www.implats.co.za/pdf/annualreports/mr-mr-statement/2009/implats-mrmr-2009.pdf [Accessed 14 October 2017].

Impala Platinum Holdings Limited. 2010. Implats Mineral Resource and Mineral Reserve Statement 2010. http://www.implats.co.za/pdf/annualreports/mr-mr-statement/2010/implats-mrmr-2010.pdf [accessed 14 October 2017].

Impala Platinum Holdings Limited. 2011. Implats Mineral Resource and Mineral Reserve Statement 2011. http://www.implats.co.za/pdf/annualreports/mr-mr-statement/2011/implats-mrmr-2011.pdf [accessed 14 October 2017].

Impala Platinum Holdings Limited. 2012. Implats Mineral Resource and Mineral Reserve Statement 2012. http://www.implats.co.za/pdf/annualreports/mr-mr-statement/2012/implats-mrmr-2012.pdf [Accessed 14 October 2017].

Impala Platinum Holdings Limited. 2013. Implats Mineral Resource and Mineral Reserve Statement 2013. http://www.implats.co.za/pdf/annualreports/mr-mr-statement/2013/implats-mrmr-2013.pdf [accessed 14 October 2017].

Impala Platinum Holdings Limited. 2014. Implats Mineral Resource and Minera Reserve Statement 2014. http://www.implats.co.za/pdf/annualreports/mr-mr-statement/2014/implats-mrmr-2014.pdf [accessed 14 October 2017].

Impala Platinum Holdings Limited. 2015. Implats Mineral Resource and Mineral Reserve Statement 2015. http://www.implats.co.za/pdf/annualreports/mr-mr-statement/2015/implats-mrmr-2015.pdf [accessed 14 October 2017].

Impala Platinum Holdings Limited. 2016. Implats Mineral Resource and Mineral Reserve Statement 2016. http://bastiongraphics.co.za/bastionir/2016/Implats-2016/Implats-MRR-2016/downloads/Implats\%20MR\% 202016.pdf [accessed 13/04/2017].

IFRS FoundATION, (n.d.). International Accounting Standard 36 Impairment of Assets. http://www.frascanada.ca/international-financial-reporting standards/resources/unaccompanied-ifrss/item45641.pdf [accessed 02/06/2018]

KITco, (n.d.). Daily Palladium Charts. http://www.kitco.com/scripts/hist_charts/ yearly_graphs.plx [accessed 10/02/2018]

KITco, (n.d.). Daily Rhodium Charts. http://www.kitco.com/scripts/hist charts/ yearly_graphs.plx [accessed 10/02/2018].

LOMBERG, K. and RuPPRECHT, S.M. 2017. The 2016 SAMREC Code. Journal of the Southern African Institute of Mining and Metallurgy, vol. 117, no. 12 , pp.1095-1100.

LoNmin PLc. 2000. Annual Report 2000. https://thevault.exchange/?get group_doc=166/1449150925-AnnualReportAccounts.pdf [accessed 14 October 2017]. 


\section{An empirical long-term commodity price range for Mineral Reserve declarations}

Lonmin PLC. 2001. Annual Report 2001. https//thevault.exchange/?get group_doc=166/1449150754-AnnualReportAccounts.pdf [accessed 14 October 2017].

LoNmin PLc. 2002. Annual Report 2002. https://thevault.exchange/?get group_doc=166/1449150530-AnnualReportAccounts.pdf [accessed 14 October 2017].

Lonmin PLc. 2003. Annual Report 2003. https//thevault.exchange/?get group doc $=166 / 1449150320$-AnnualReportAccounts.pdf [accessed 14 October 2017].

Lonmin PLC. 2004. Annual Report 2004. https://thevault.exchange/?get group doc=166/1449149849-AnnualReportAccounts.pdf [accessed 14 October 2017].

LoNMIN PLC. 2005. Mineral Resources and Reserves 2005. https://thevault.exchange/?get_group_doc=166/1449149275MineralResourceMineralReserveStatement.pdf [accessed 14 October 2017].

LoNmIN PLC. 2006. Mineral Resources and Reserves 2006 https://thevault.exchange/?get_group_doc $=166 / 1449148329$ MineralResourceMineralReserveStatement.pdf [accessed 14 October 2017].

LoNMIN PLC. 2007. Mineral Resources and Reserves 2007. https://thevault.exchange/?get group_doc $=166 / 1449145281$ MineralResourceMineralReserveStatement.pdf [accessed 14 October 2017].

LoNMIN PLC. 2008. Mineral Resources and Reserves 2008. https://thevault.exchange/?get_group_doc=166/1449142943MineralResourceMineralReserveStatement.pdf [accessed 14 October 2017].

LoNMIN PLC. 2009. Mineral Resources and Reserves Statement 2009. https://thevault.exchange/?get_group_doc=166/1449141739MineralResourceMineralReserveStatement.pdf [accessed 14 October 2017].

LoNmin PLc. 2010. Mineral Resources and Reserves Statements 2010. https://thevault.exchange/?get_group_doc=166/1449140716MineralResourceMineralReserveStatement.pdf [accessed 14 October 2017].

LoNmIN PLc. 2011. Mineral Resources and Reserves Statements 2011 https://thevault.exchange/?get_group_doc $=166 / 1449138821$ MineralResourceMineralReserveStatement.pdf [accessed 14 October 2017].

LoNMIN PLC. 2012. Mineral Resources and Reserves Statements 2012 https://thevault.exchange/?get_group_doc=166/1449136164MineralResourceMineralReserveStatement.pdf [accessed 14 October 2017].

Lonmin PLC. 2013. Mineral Resources and Reserves Statements 2013 https://thevault.exchange/?get_group_doc $=166 / 1449133312$ MineralResourceMineralReserveStatement.pdf [accessed 14 October 2017].

LoNmIN PLc. 2014. Mineral Resources and Reserves Statements 2014 https://thevault.exchange/?get_group_doc=166/1449131677MineralResourceMineralReserveStatement.pdf [accessed 14 October 2017].

LoNMIN PLC. 2015. Mineral Resources and Reserves Statements 2015. https://thevault.exchange/?get group doc $=166 / 1453806485$ 2015_RR_Statement.pdf [accessed 14 October 2017].

LoNMIN PLC. 2016. Mineral Resources and Reserves Statements 2018. https://thevault.exchange/?get group doc=166/1507013512-LonminResource-Statement-2016.pdf [accessed 14 October 2017].

MacDiarmid J., Tholana, T., and Musingwini, C. 2018. Analysis of key value drivers for major mining companies for the period 2006-2015. Resources Policy, vol. 56, pp.16-30

МASEKо, V. 2018. An assessment of the long-term commodity price assumptions on the Mineral Reserve estimates of South African gold and platinum mining companies from 2000 to 2016 . MSc research report, University of the Witwatersrand, South Africa.

METALARY, (Not dated). Iridium price. https://www.metalary.com/iridium-price/ [accessed 10 February 2018].

MusingwinI, C. 2018. Keynote Address: The importance of teaching mineral reporting and valuation codes in mine planning and valuation discourses within a mining engineering curriculum. Proceedings of Society of Mining Professors 6th Regional Conference, Johannesburg, South Africa, 12-13 March 2018, Southern African Institute of Mining and Metallurgy, Johannesburg. pp. 237-244.

NjowA, G. AND Musingwini, C. 2018. A framework for interfacing mineral asse valuation and financial reporting. Resources Policy, vol.56. pp. 3-15.

Northam Platinum Limited. 2000. Resources and Reserves 2000. http://www.northam.co.za/images/publications/ar/ar_2000/resources_and reserves.html [accessed 14 October 2017].

Northam Platinum Limited. 2001. Resources and Reserves 2001. http://www.northam.co.za/images/publications/ar/ar_2001/resources and _reserves.html [accessed 14 October 2017].

Northam Platinum Limited. 2002. Annual Report 2002. http://www.northam.co.za/downloads/send/39-2002/495-annual-report2002 [accessed 14 October 2017].

Northam Platinum Limited. 2003. Annual Report 2003. http://www.northam.co.za/downloads/send/38-2003/494-annual-report2003 [accessed 14 October 2017].

Northam Platinum Limited. 2004. Annual Report 2004. http://www.northam.co.za/downloads/send/37-ar-2004/493-annualreport-2004 [accessed 14 October 2017].

Northam Platinum Limited. 2005. Annual Report 2005. http://www.northam.co.za/downloads/send/36-2005/492-annual-report2005 [accessed 14 October 2017]

Northam Platinum Limited. 2006. Annual Report 2006. http://www.northam.co.za/downloads/send/35-2006/491-annual-report2006 [accessed 14 October 2017].

Northam Platinum Limited. 2007. Annual Report 2007. http://www.northam.co.za/downloads/send/34-2007/490-annual-report2007 [accessed 14 October 2017].

Northam Platinum Limited. 2008. Annual Report 2008. http//www.northam.co.za/downloads/send/33-2008/489-annual-report2008 [accessed 14 October 2017].

Northam Platinum Limited. 2009. Annual Report 2009. http://www.northam.co.za/downloads/send/32-2009/488-annual-report2009 [accessed 14 October 2017]

Northam Platinum Limited. 2010. Annual Report 2010. http://www.northam.co.za/downloads/send/31-2010/487-annual-report2010 [accessed 14 October 2017].

Northam Platinum Limited. 2011. Annual Integrated Report 2011 http//www.northam.co.za/downloads/send/30-2011/486-annual-report2011 [accessed 14 October 2017].

Northam Platinum Limited. 2012. Annual Integrated Report 2012 http://northam.integrated-report.com/2012/download/NHM-IR2012.pdf [accessed 14 October 2017].

Northam Platinum Limited. 2013. Annual Integrated Report 2013. http://www.northam.co.za/downloads/send/25-2013/483-annualintegrated-report-2013 [accessed 14 October 2017].

Northam Platinum Limited. 2014. Annual Integrated Report 2014 http://northam.integrated-report.com/2014/downloads/NHM-IR14.pdf [accessed 14 October 2017].

Northam Platinum Limited. 2015. Annual Integrated Report 2015. http://northam.integrated-report.com/2015/downloads/NHM-IR15.pdf [accessed 14 October 2017].

Northam Platinum Limited. 2016. Annual Integrated Report 2016. http://northam.integrated-report.com/2016/download/NHM-AIR16.pdf [accessed 14 October 2017].

Penn State Eberly College of Science, (Not dated). 1.5 - The coefficient of determination, r-squared, https://newonlinecourses.science.psu.edu/ stat501/node/255/ [accessed 14/01/2019].

QuANDL, (Not dated). Ruthenium prices. https://www.quandl.com/data/JOHNMATT/RUTH-Ruthenium-Prices [accessed 10/02/2018].

Sibanye Gold Limited. 2013. Mineral Resources and Mineral Reserves 2013. http://reports.sibanyegold.co.za/2013/download/SGL-RR13.pdf [accessed 14 October 2017].

SibANYE Gold Limited. 2014. Mineral Resources and Mineral Reserves 2014. http://reports.sibanyegold.co.za/2014/download/SGL-RR14.pdf [accessed 14 October 2017]

Sibanye Gold Limited. 2015. Mineral Resources and Mineral Reserves 2015. http://reports.sibanyegold.co.za/2015/download/SGL-RR15.pdf [accessed 14 October 2017]

Sibanye Gold Limited. 2016. Mineral Resources and Mineral Reserves Report 2016. http://reports.sibanyegold.co.za/2016/download/SGL-RR16.pdf [Accessed 14 October 2017].

SNL Metals \& Mining. (Not dated). Gold price chart. https://www.snl.com/web/client?auth=inherit\#industry/priceChart [accessed 10/02/2018].

SNL Metals \& Mining. (Not dated). Gold price chart. https://www.snl.com/web/client?auth=inherit\#industry/priceChart [accessed 10/02/2018].

StATISTICS South AfricA. 2017. Mining Industry 2015 Report no. 20-01-02. http://www.statssa.gov.za/publications/Report-20-01-02/Report-20-01022015.pdf [accessed 25/07/2017].

SAMREC. 2016. South African Mineral Resource Committee. The South African Code for the Reporting of Exploration Results, Mineral Resources and Mineral Reserves (the SAMREC Code). 2016 Edition.

http://www.samcode.co.za/codes/category/8-reporting codes? download=120: samrec 